\title{
Universiteit
}

Leiden

The Netherlands

\section{Participatory assessment of development in Africa}

Dietz, A.J.; Baud, I.; Pouw, N.

\section{Citation}

Dietz, A. J. (2012). Participatory assessment of development in Africa. Local Governancne And Poverty In Developing Nations, 214-239. Retrieved from

https://hdl.handle.net/1887/19529

Version: $\quad$ Not Applicable (or Unknown)

License:

Downloaded from: https://hdl.handle.net/1887/19529

Note: To cite this publication please use the final published version (if applicable). 


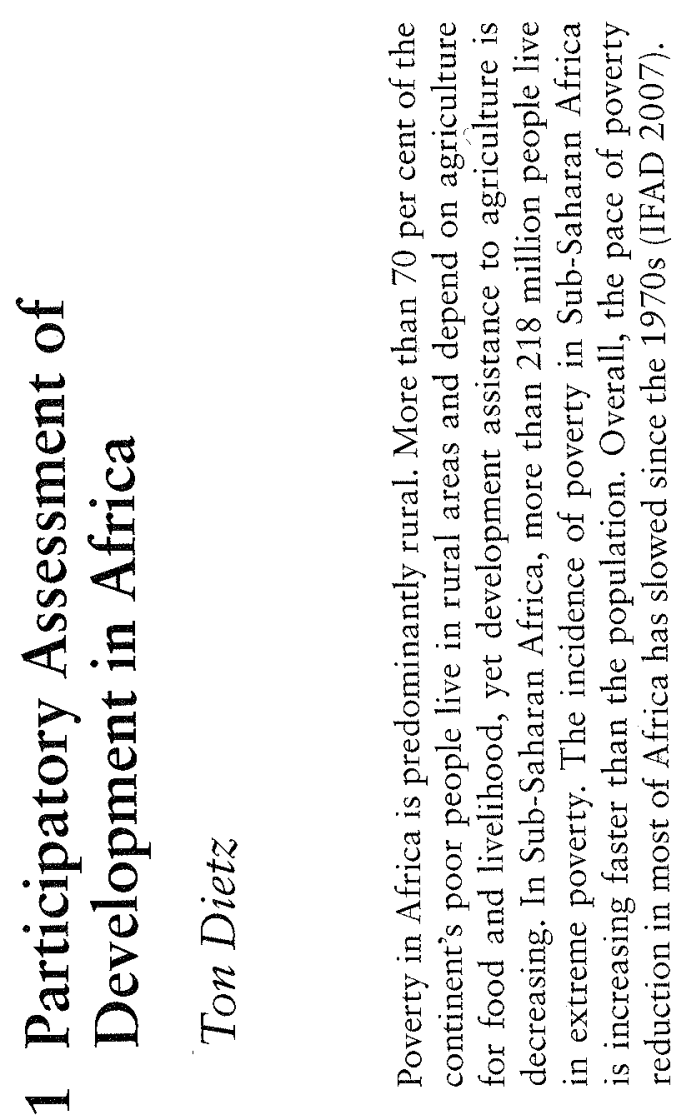

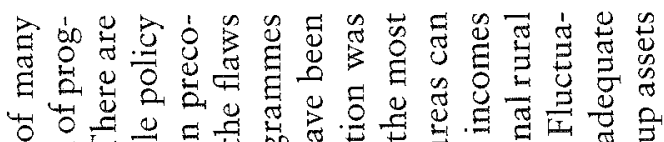

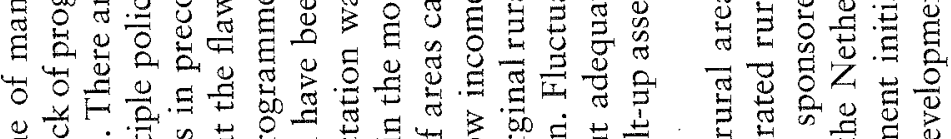

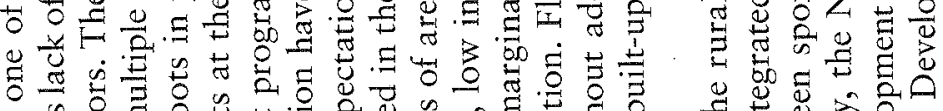

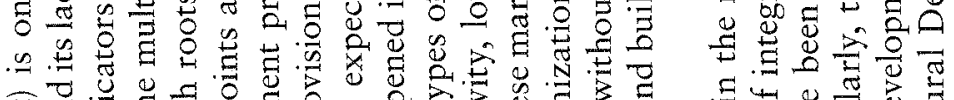

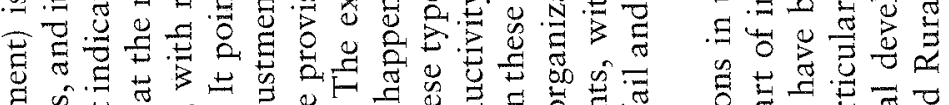
等

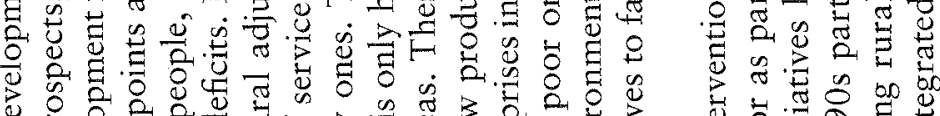

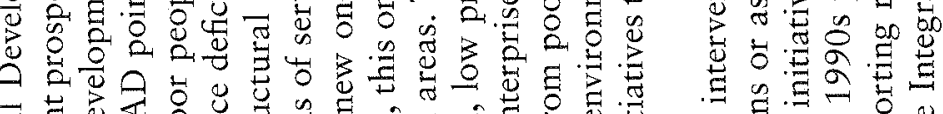

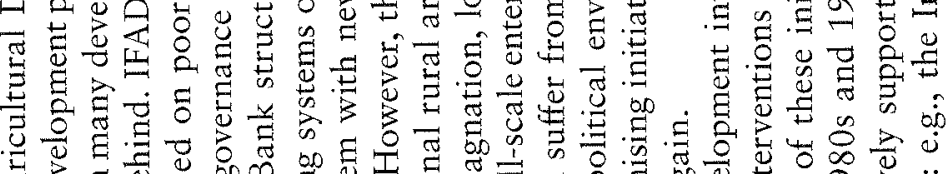

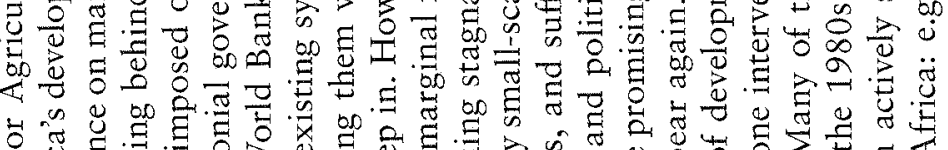

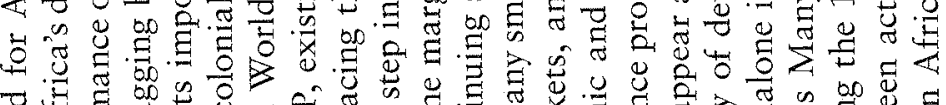

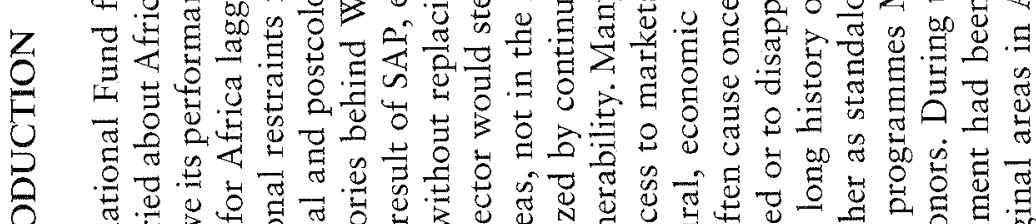

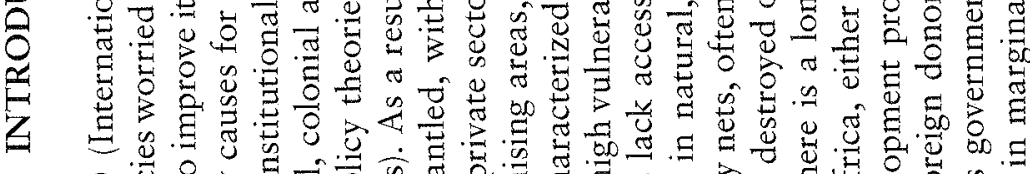

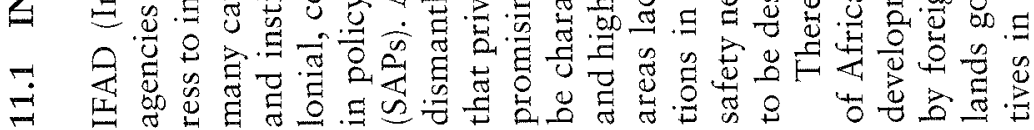




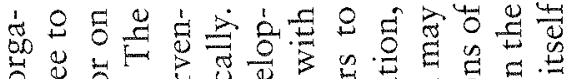

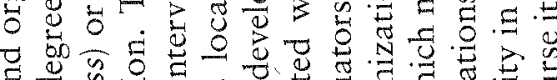

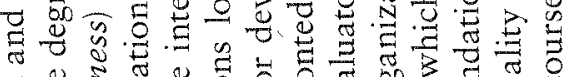

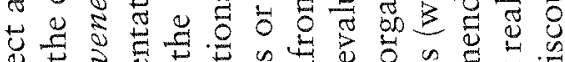

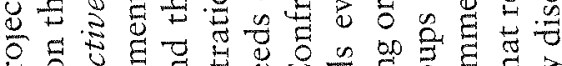

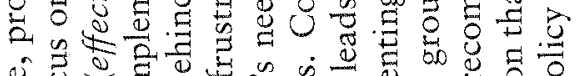

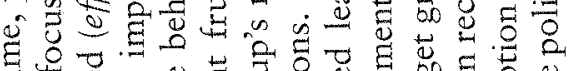

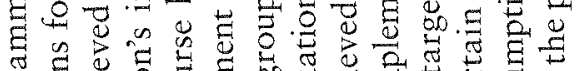

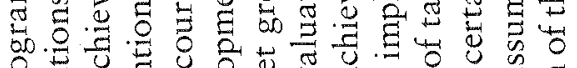

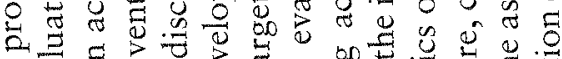

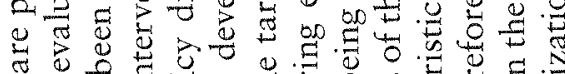

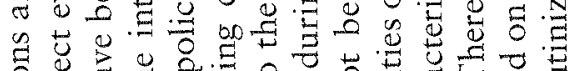
.

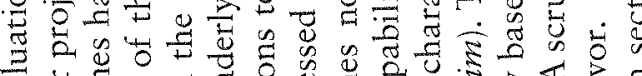

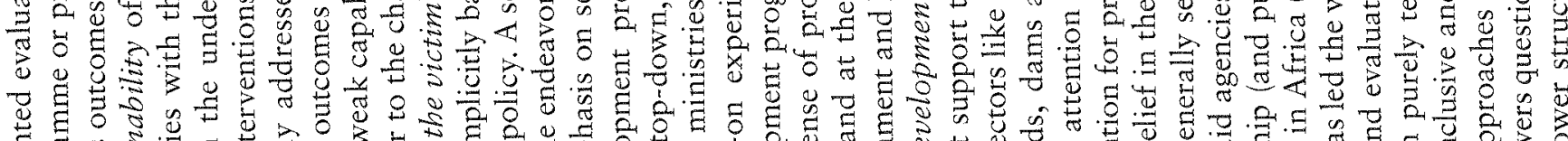

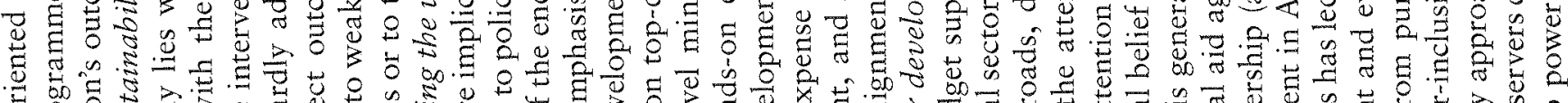

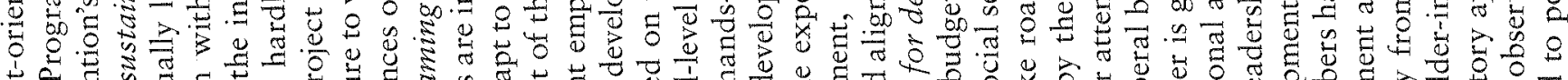

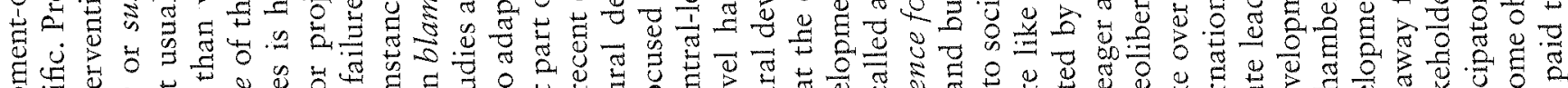

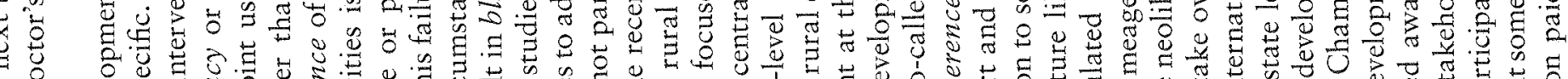

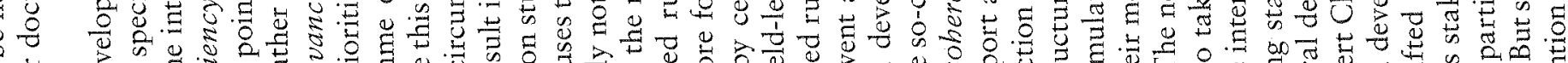

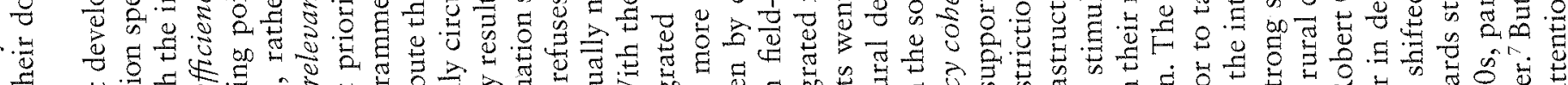

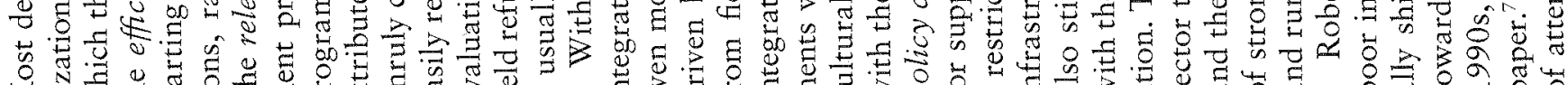

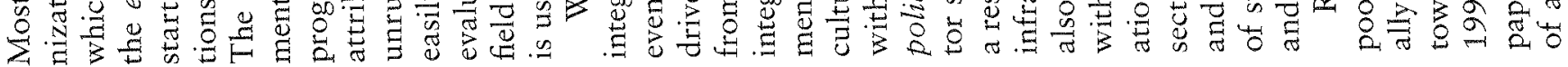

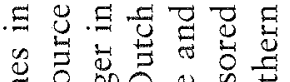

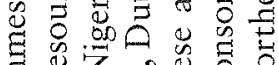

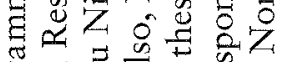
क人

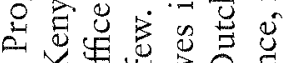

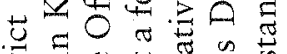

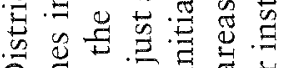

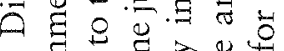

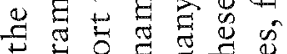

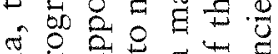

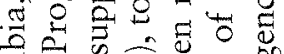

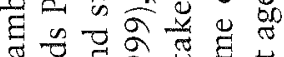
N घ워료

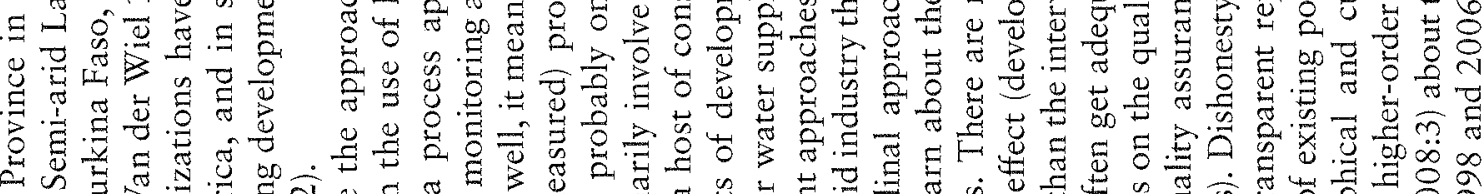

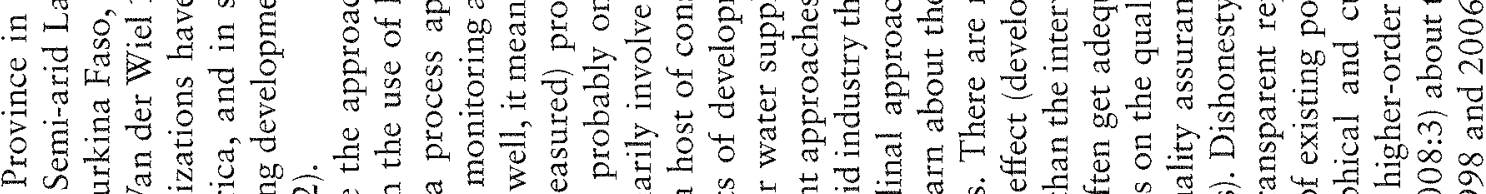

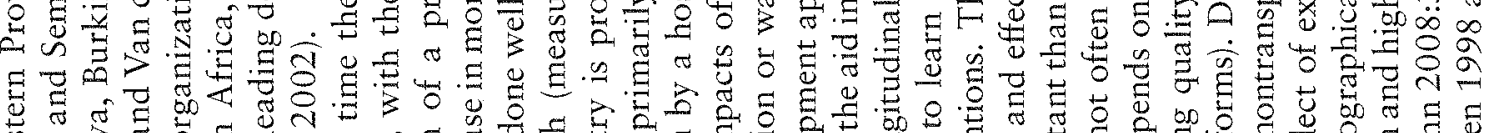
论

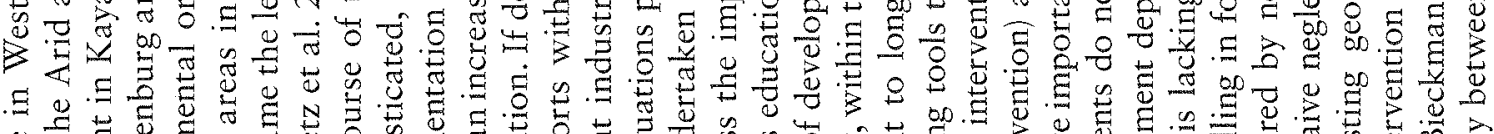

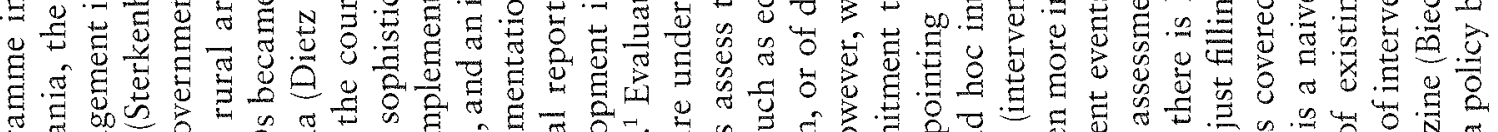

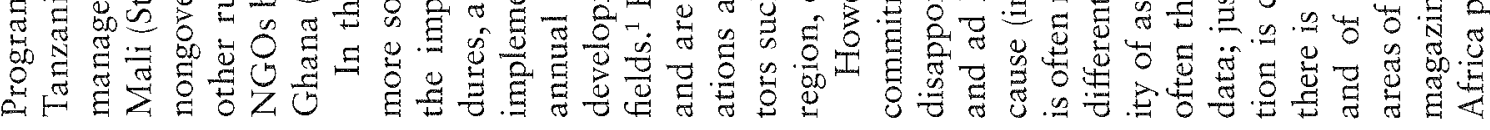

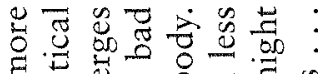

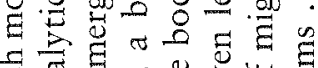

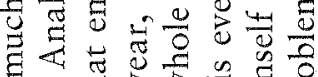

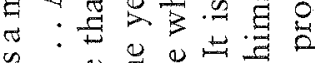

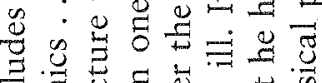

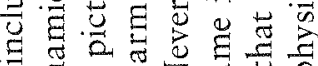

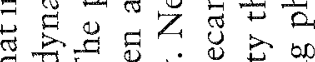
-

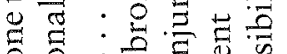

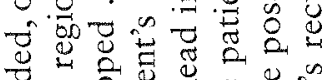

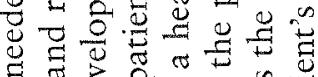

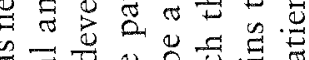

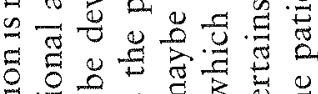

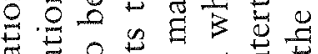

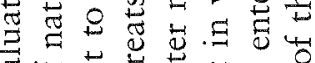

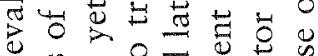

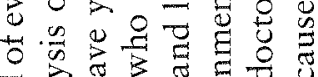
证可

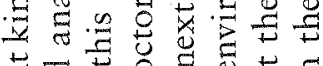

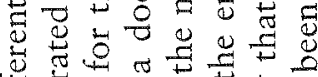

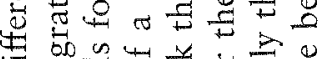

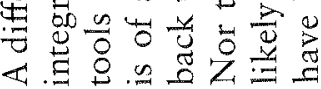




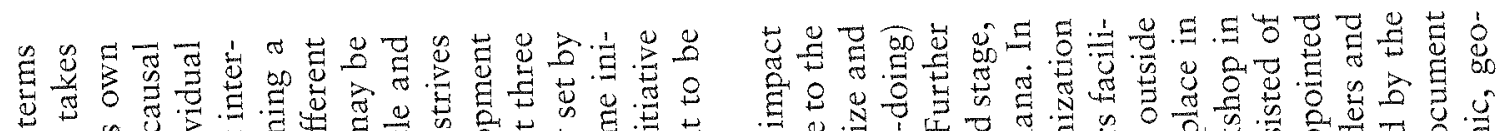
$\underline{\Xi}$

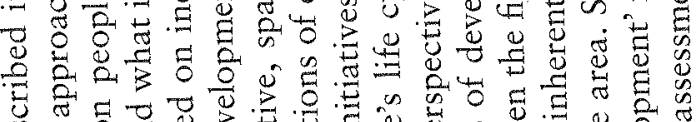

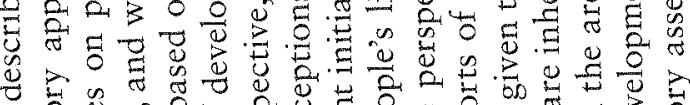

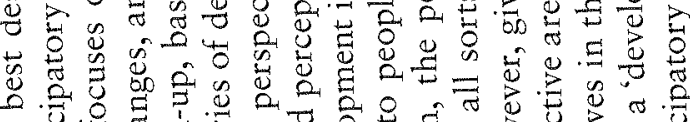

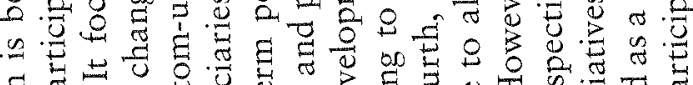

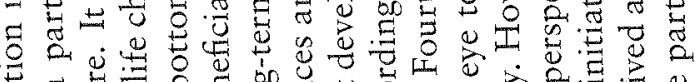

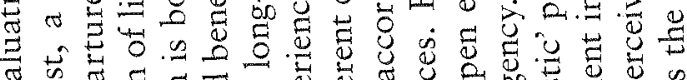

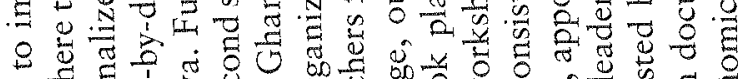

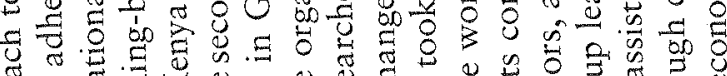

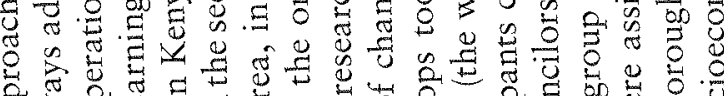

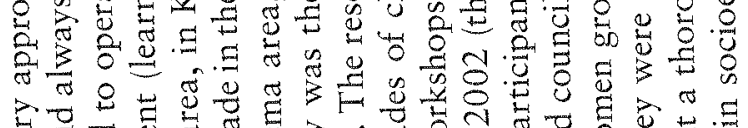

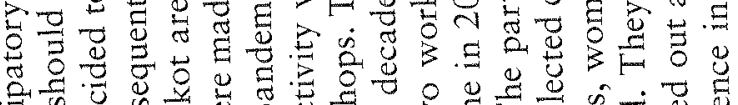

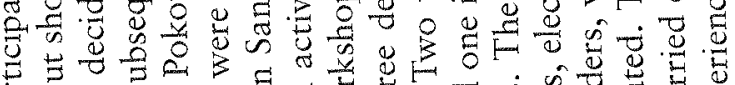

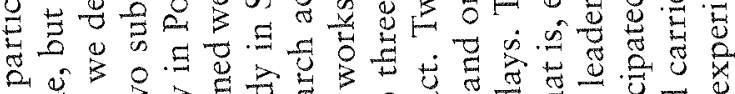

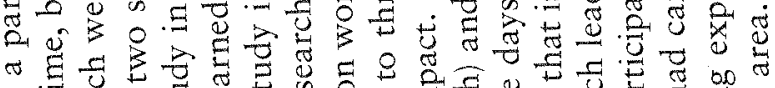

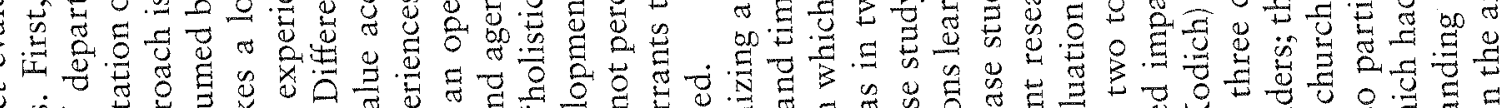

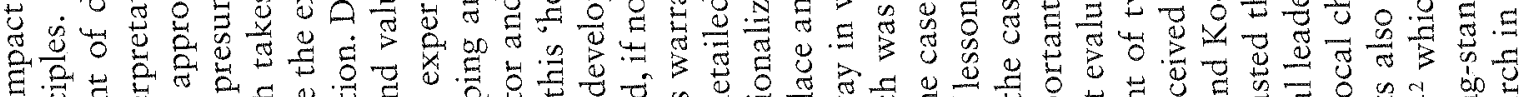

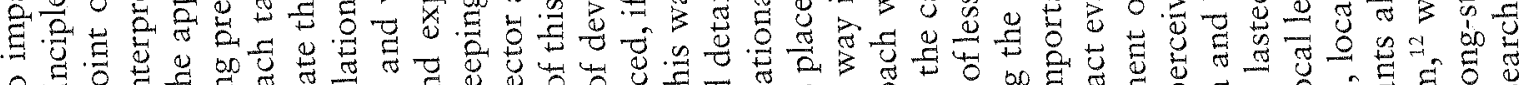

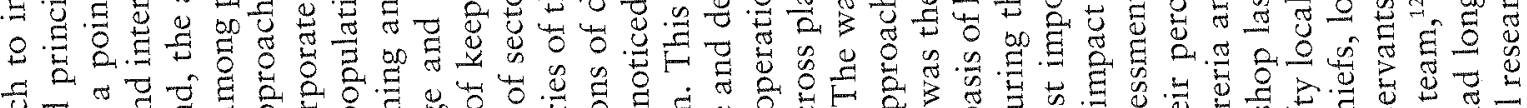

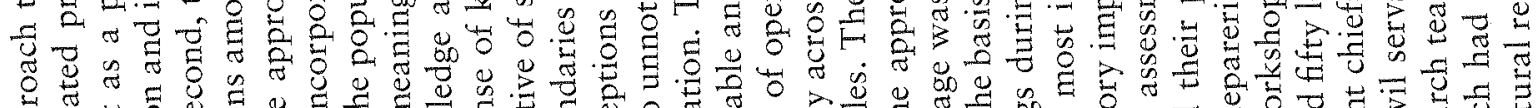

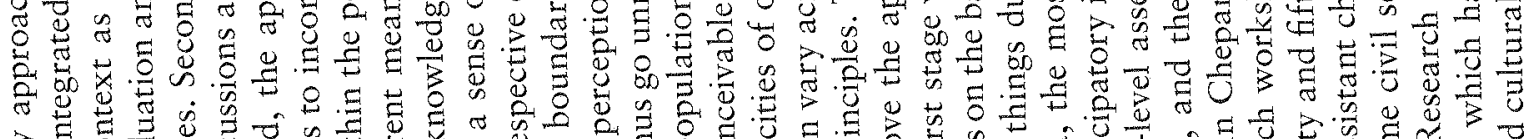

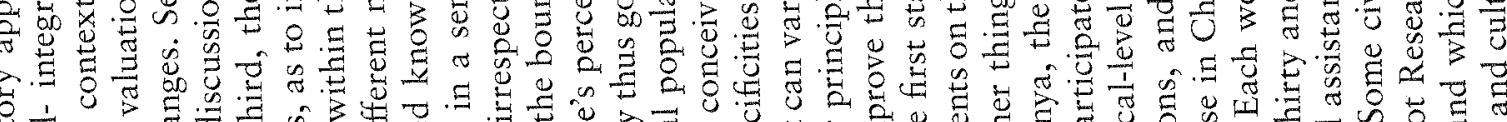

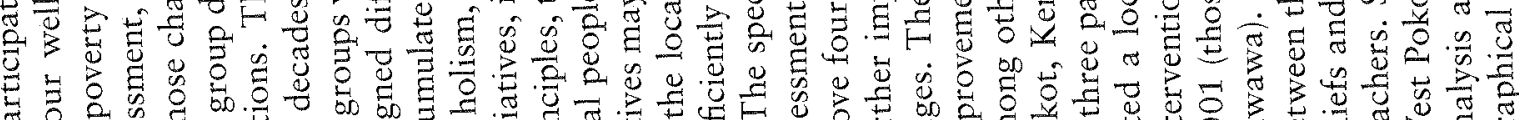

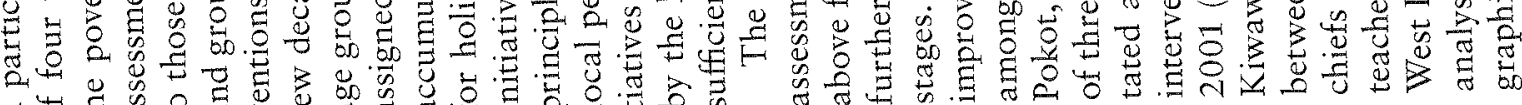

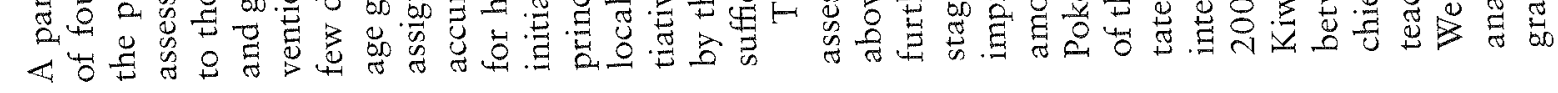

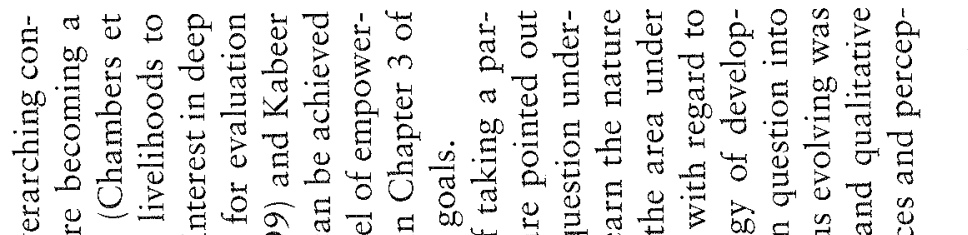

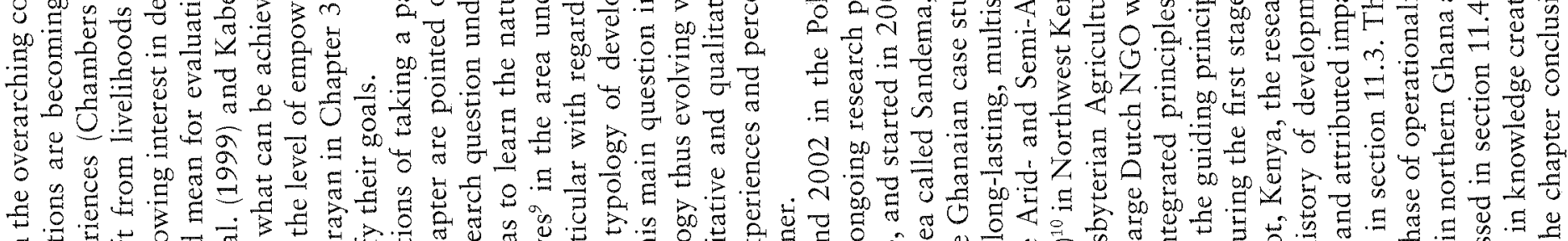

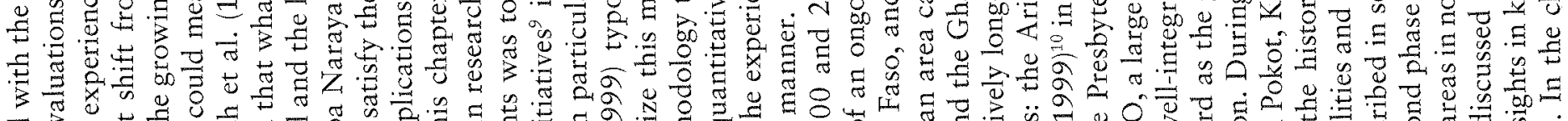

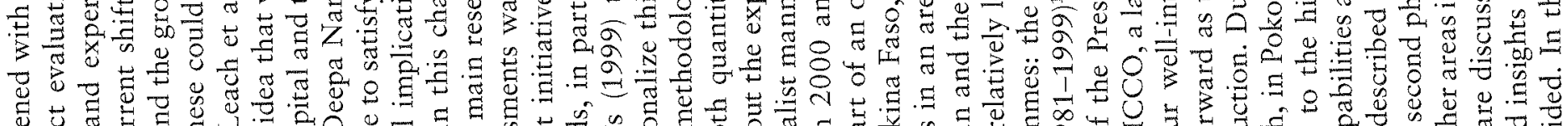

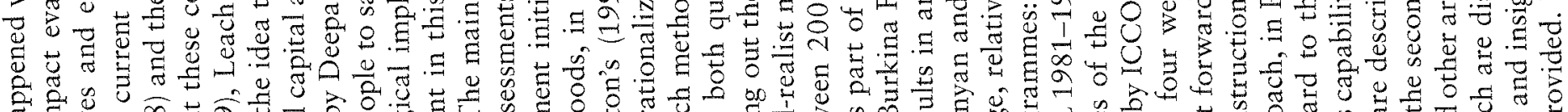

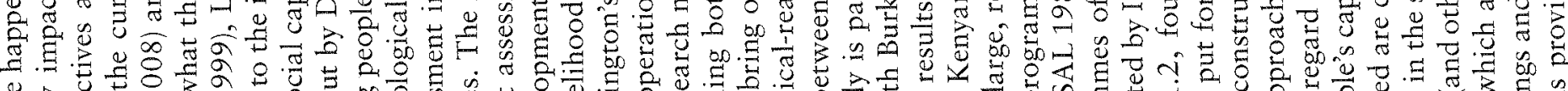

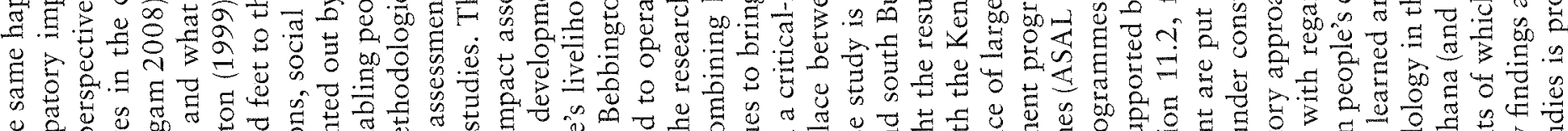

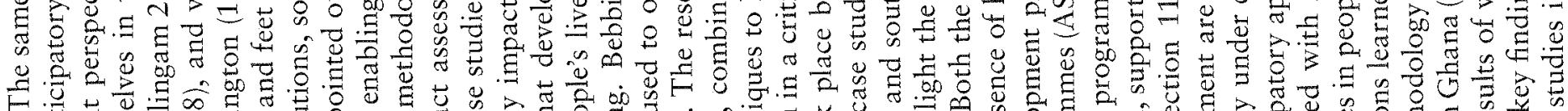

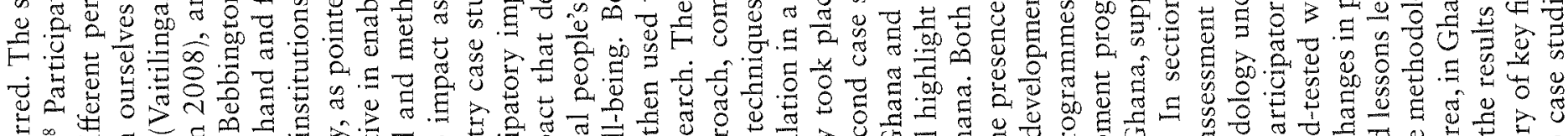
类:

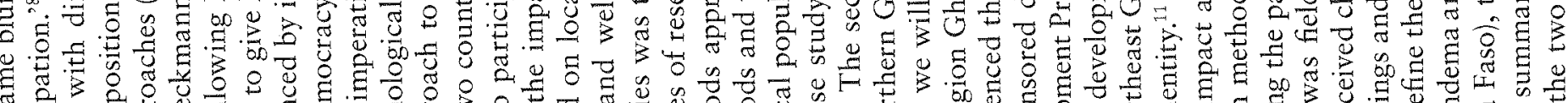

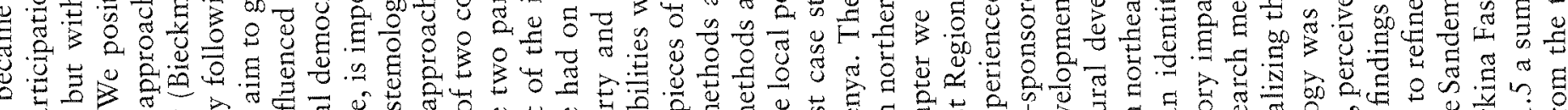
等

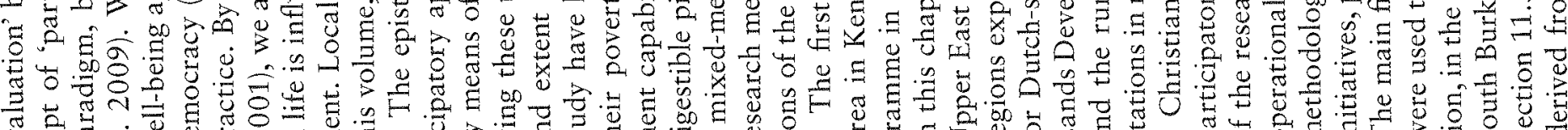

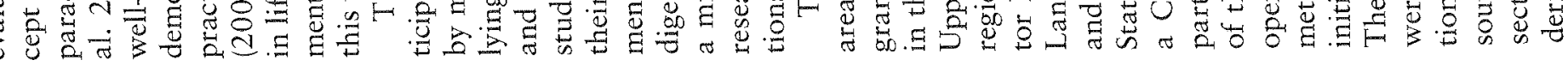


.

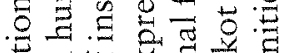

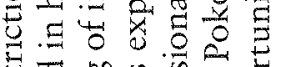

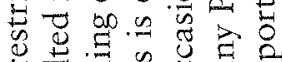

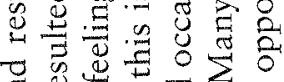

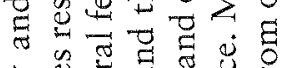

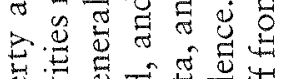
离.

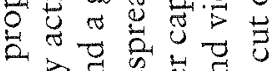

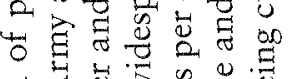

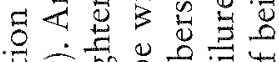

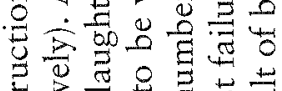

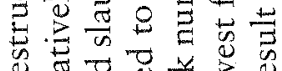

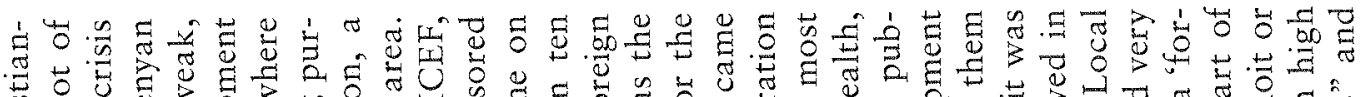

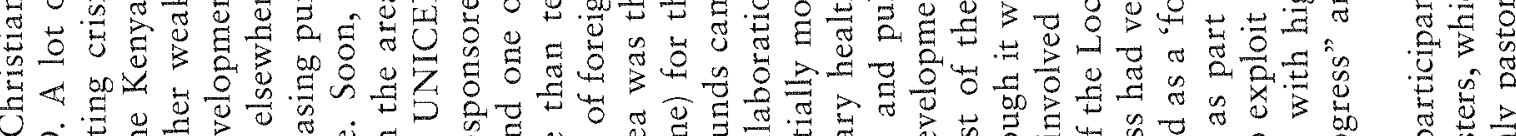

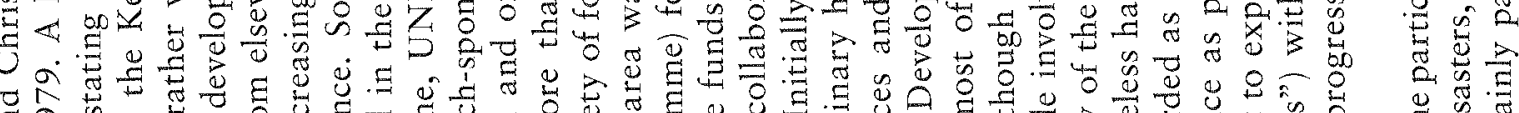

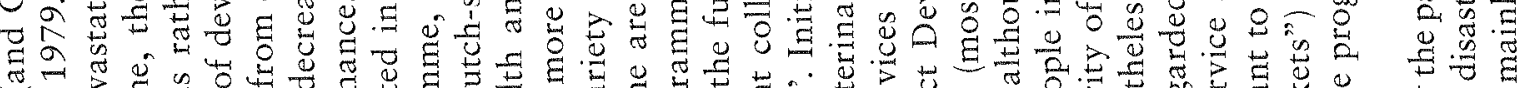
ब-

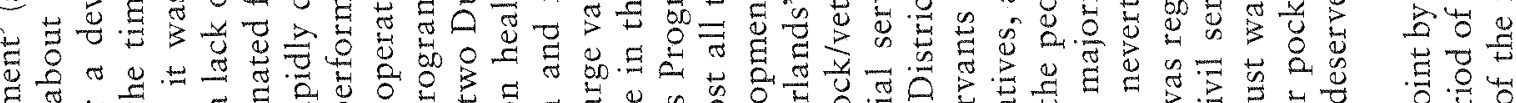
更

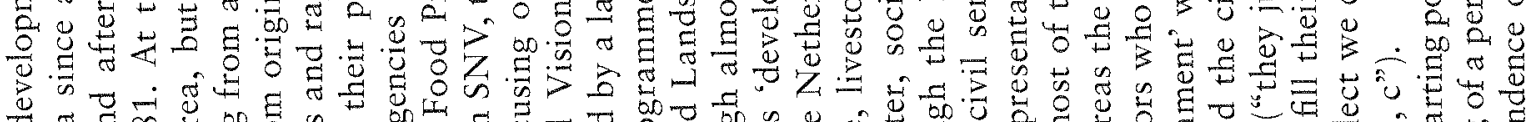

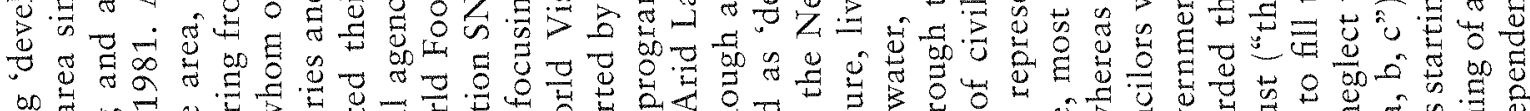

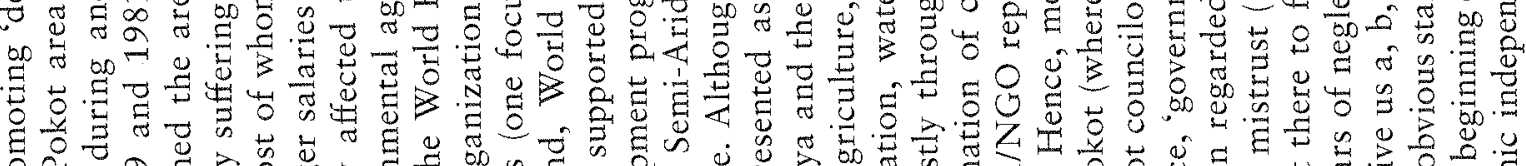

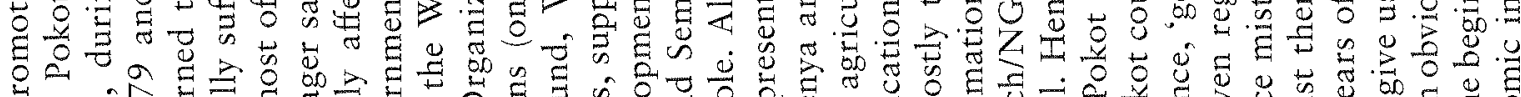

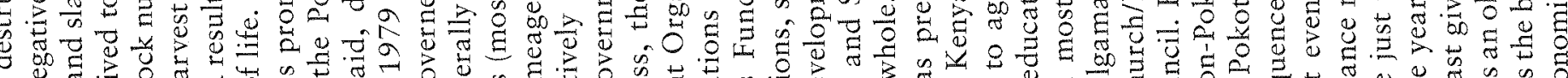

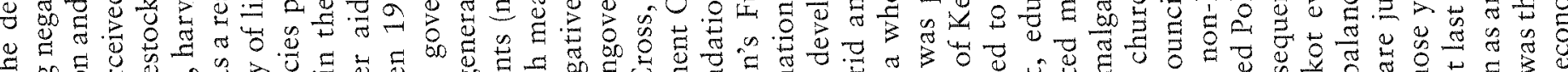

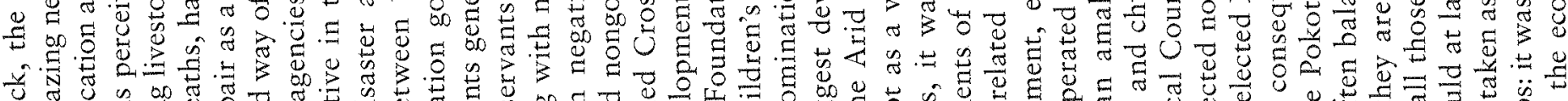

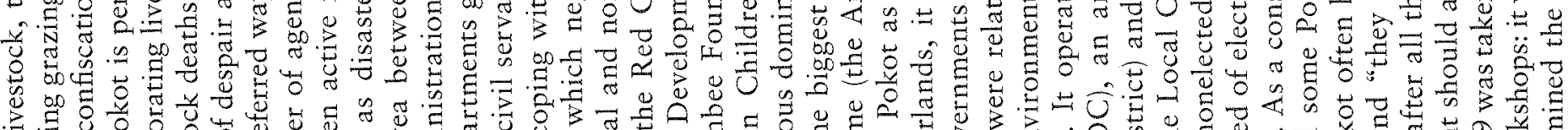

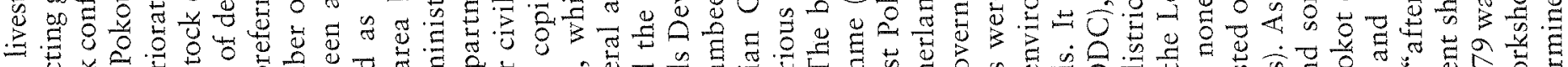

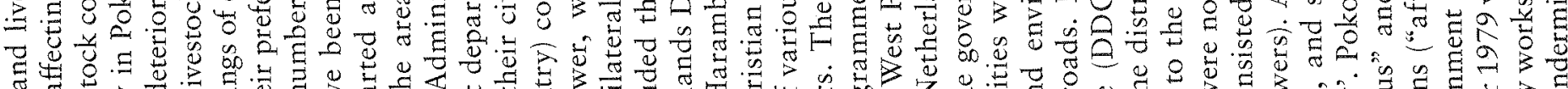

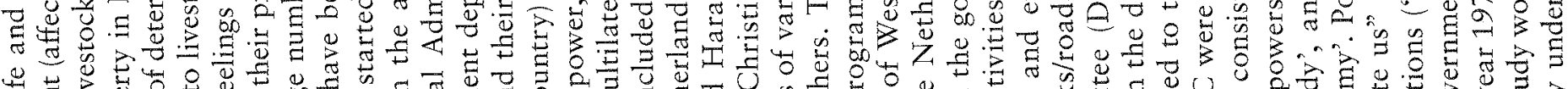

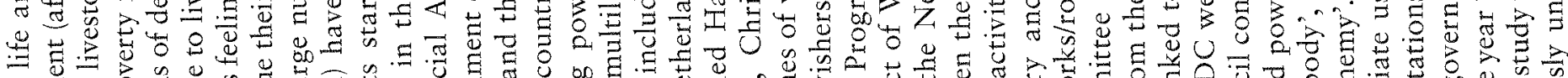

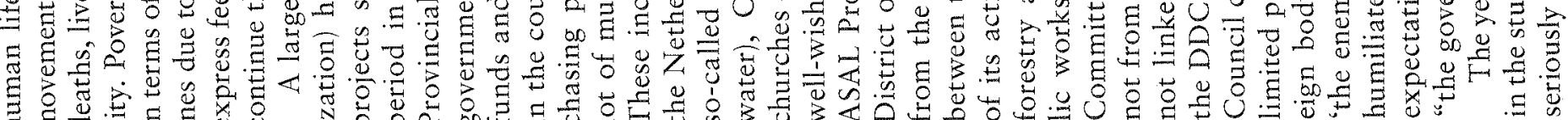

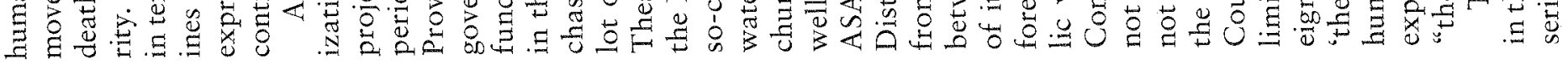

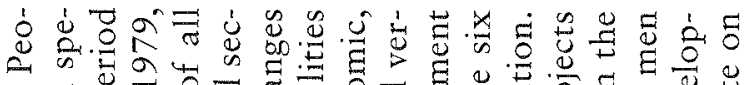

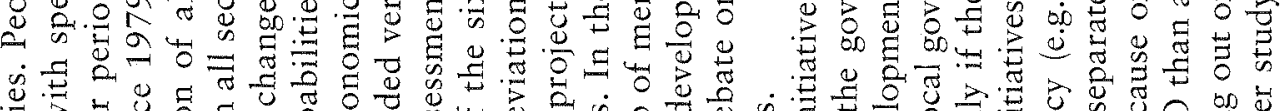

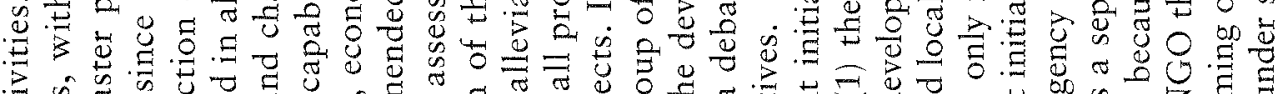
हीं के

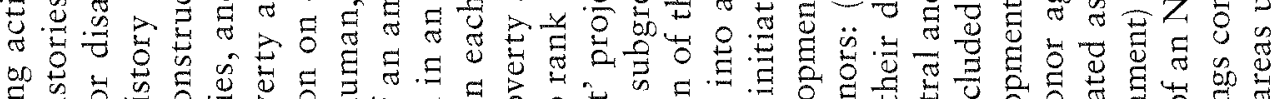

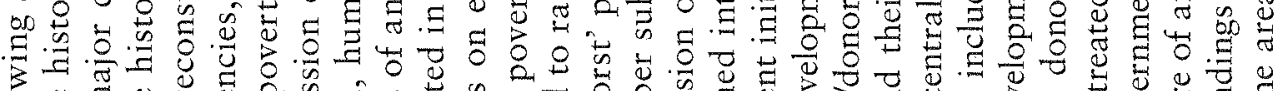

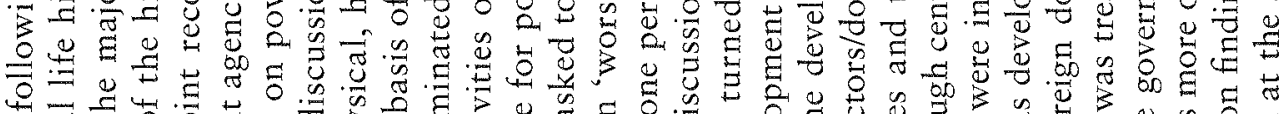

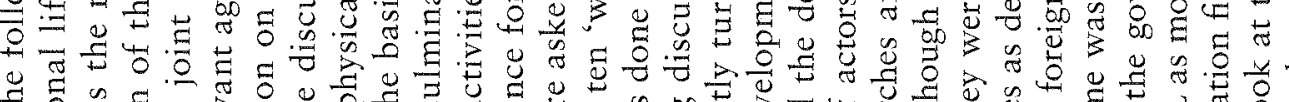

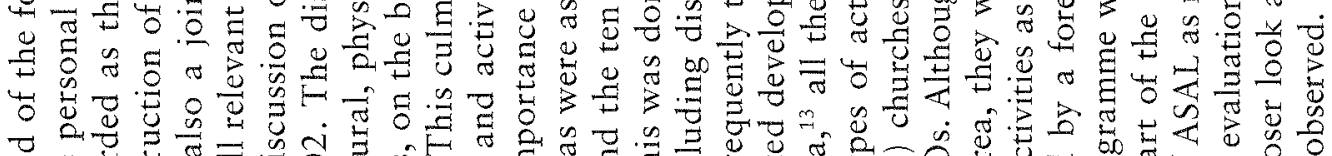

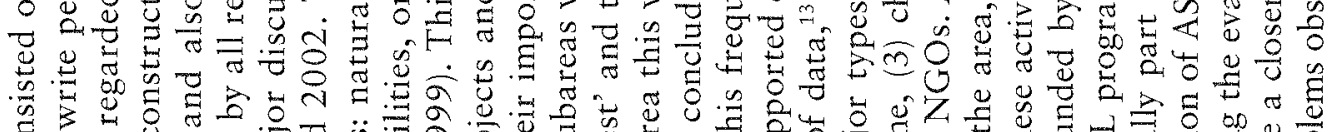

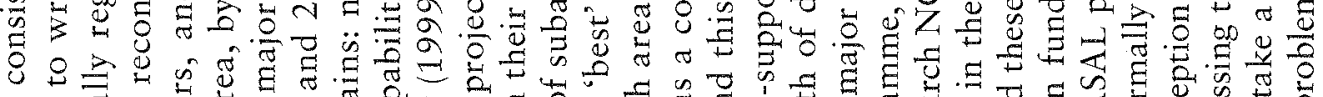

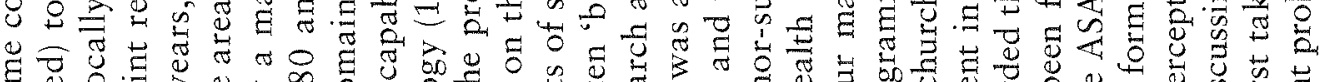

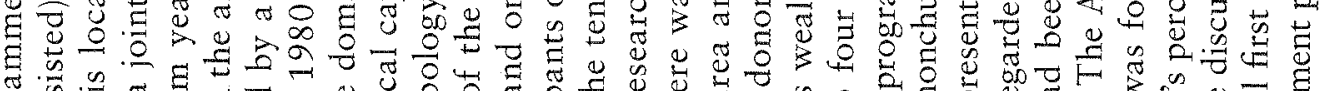

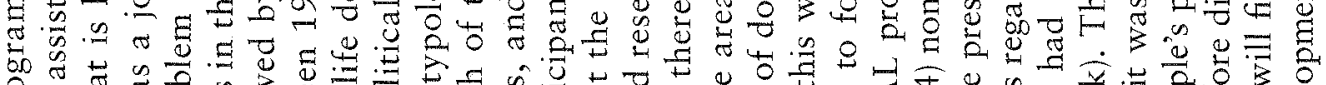

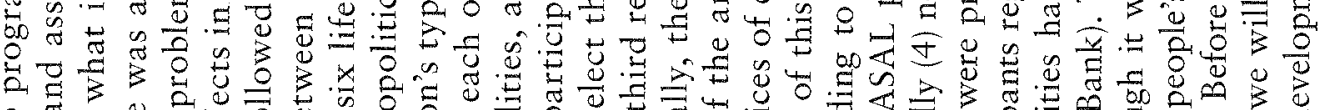

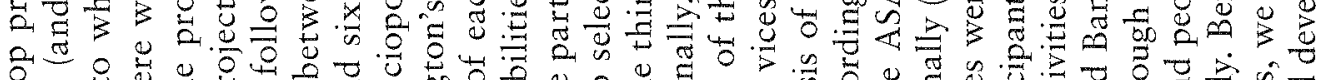

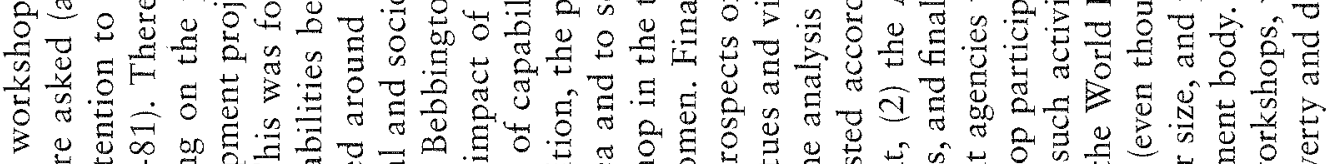

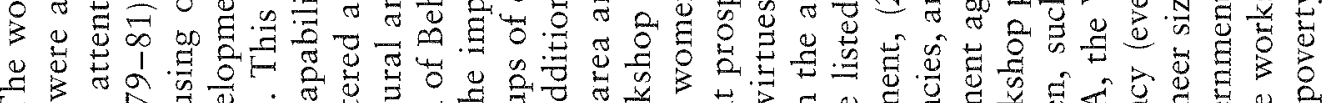

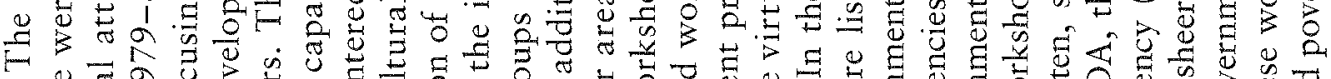

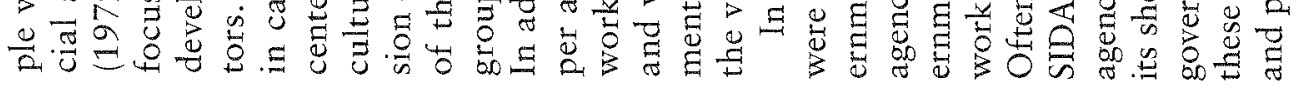

ज्ञ 8 की

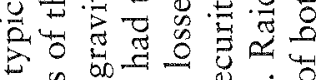

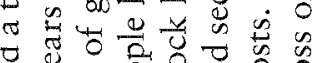

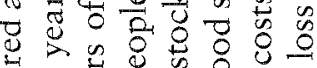

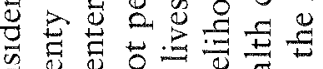

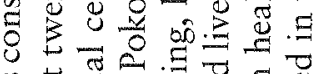

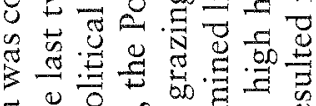

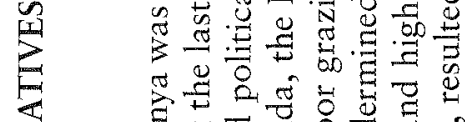

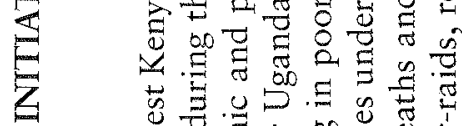

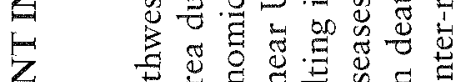

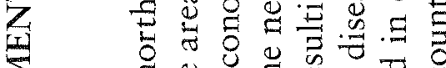
过

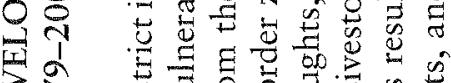

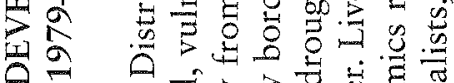

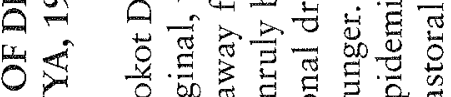

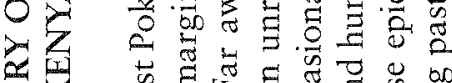

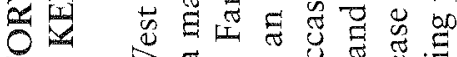

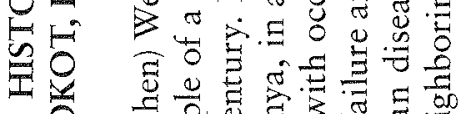

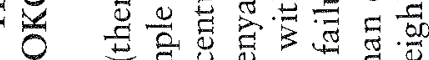
m स ज्ञ

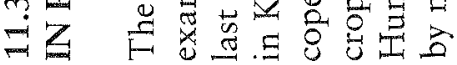




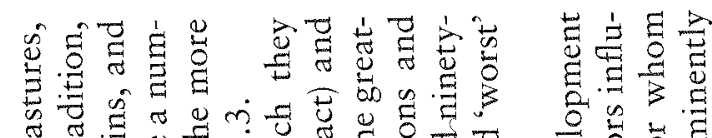
\&

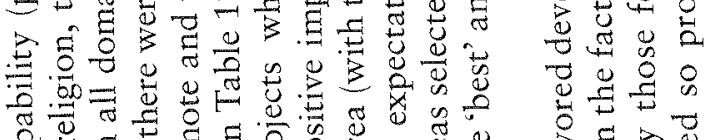

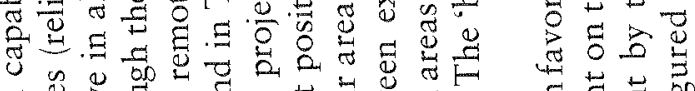

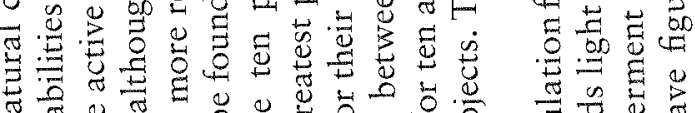

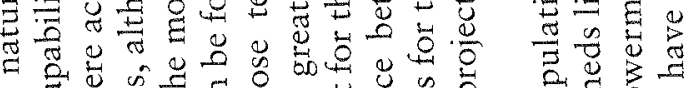

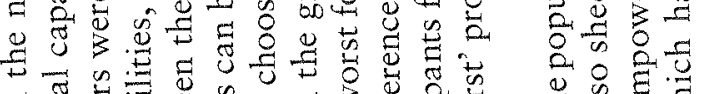

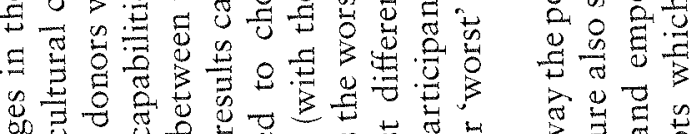

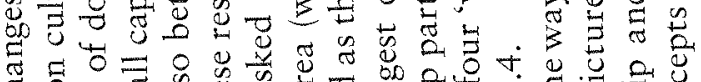

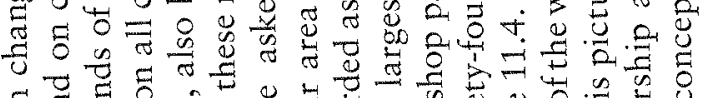

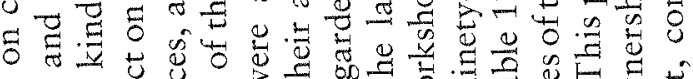

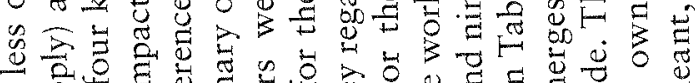

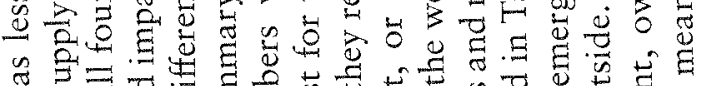

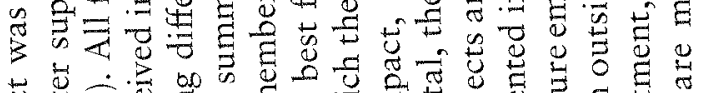

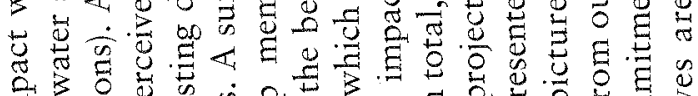

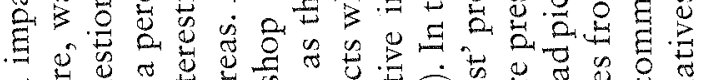

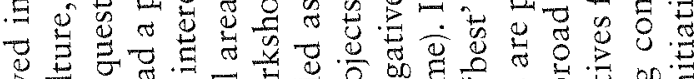

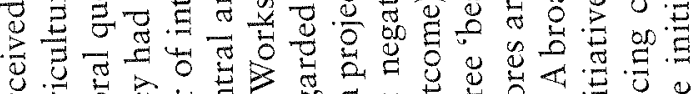

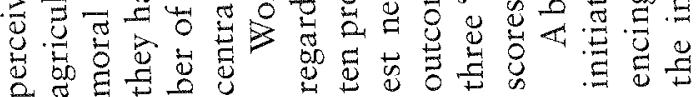

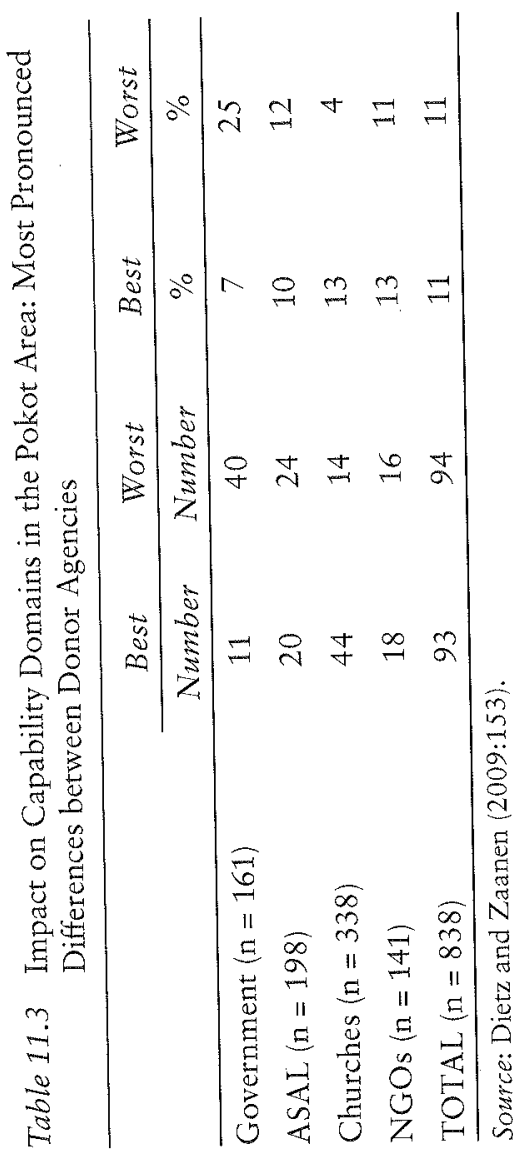

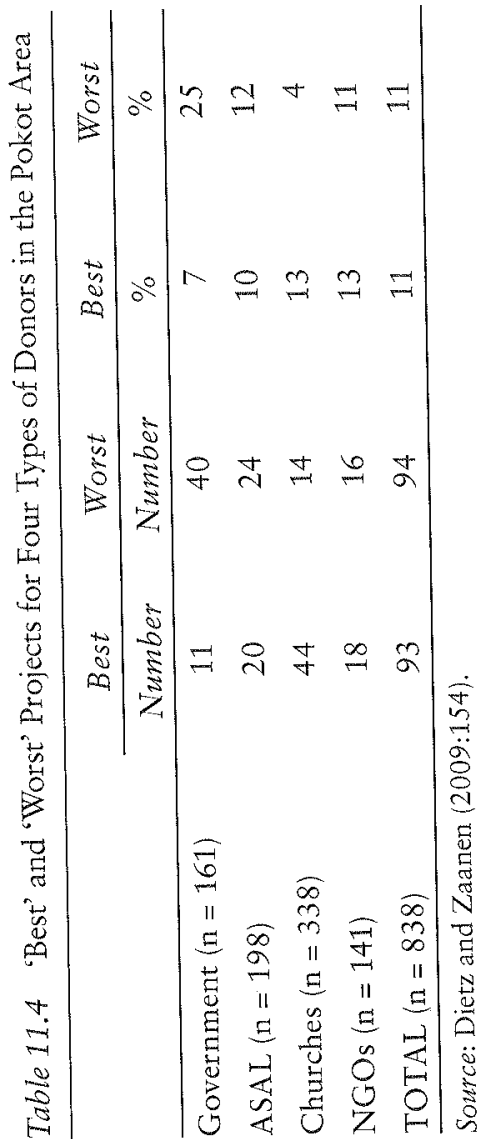

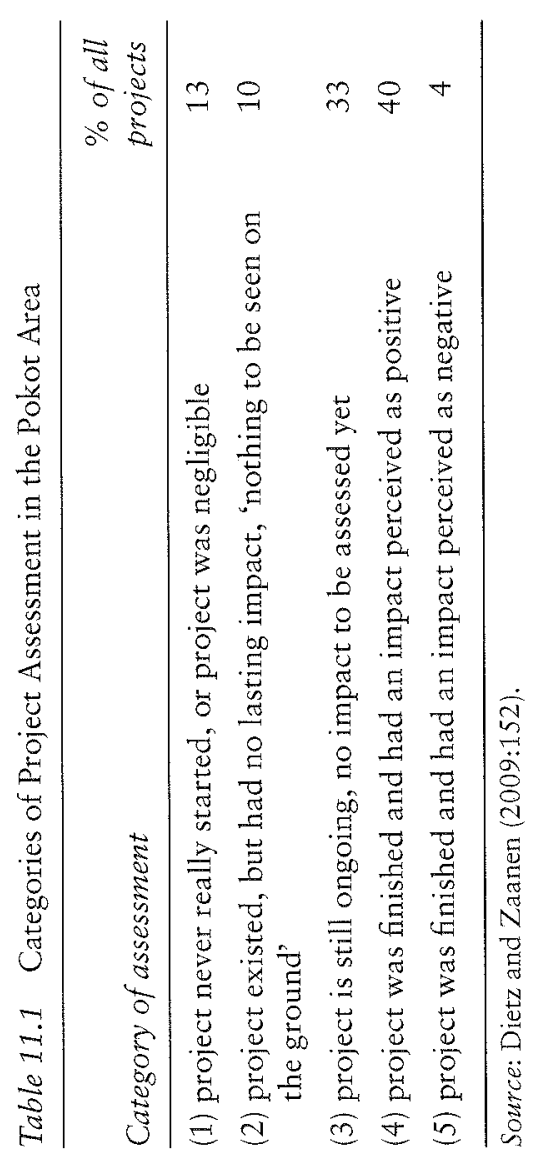

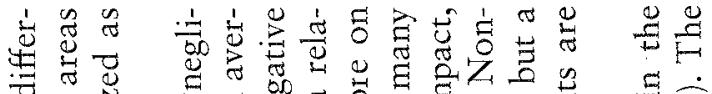
๙

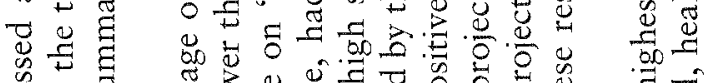

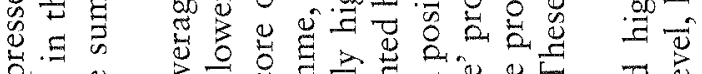

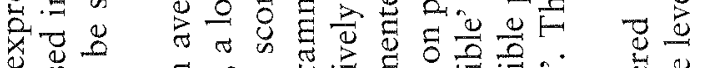

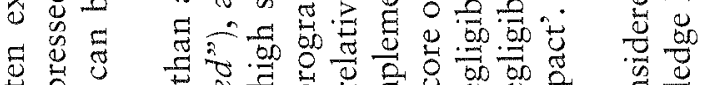

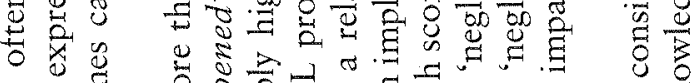

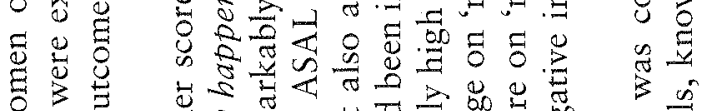

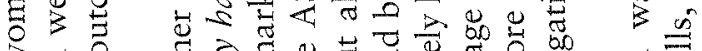

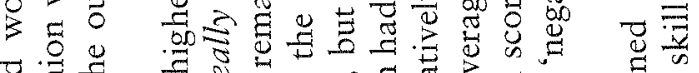
च्च

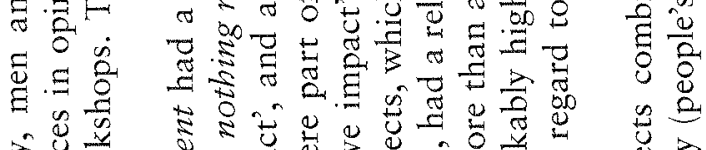

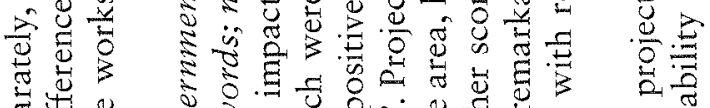

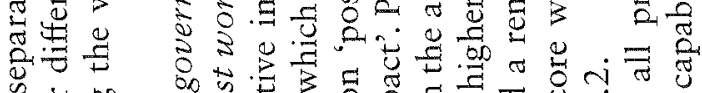

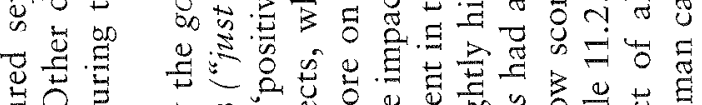

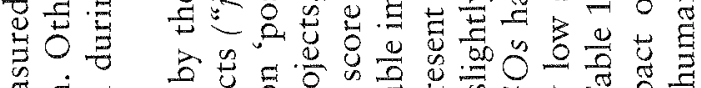

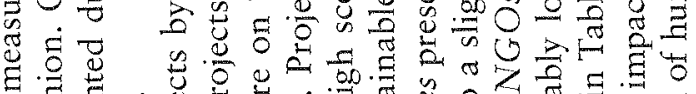

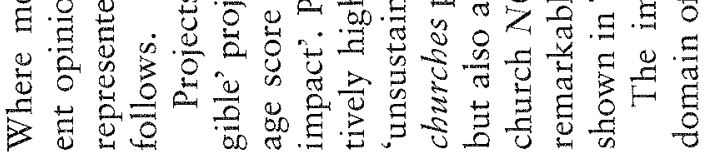

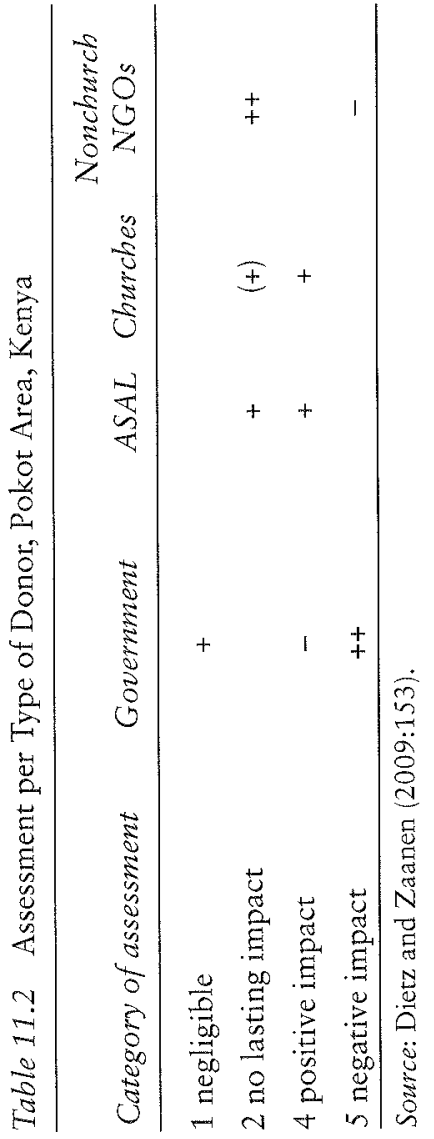




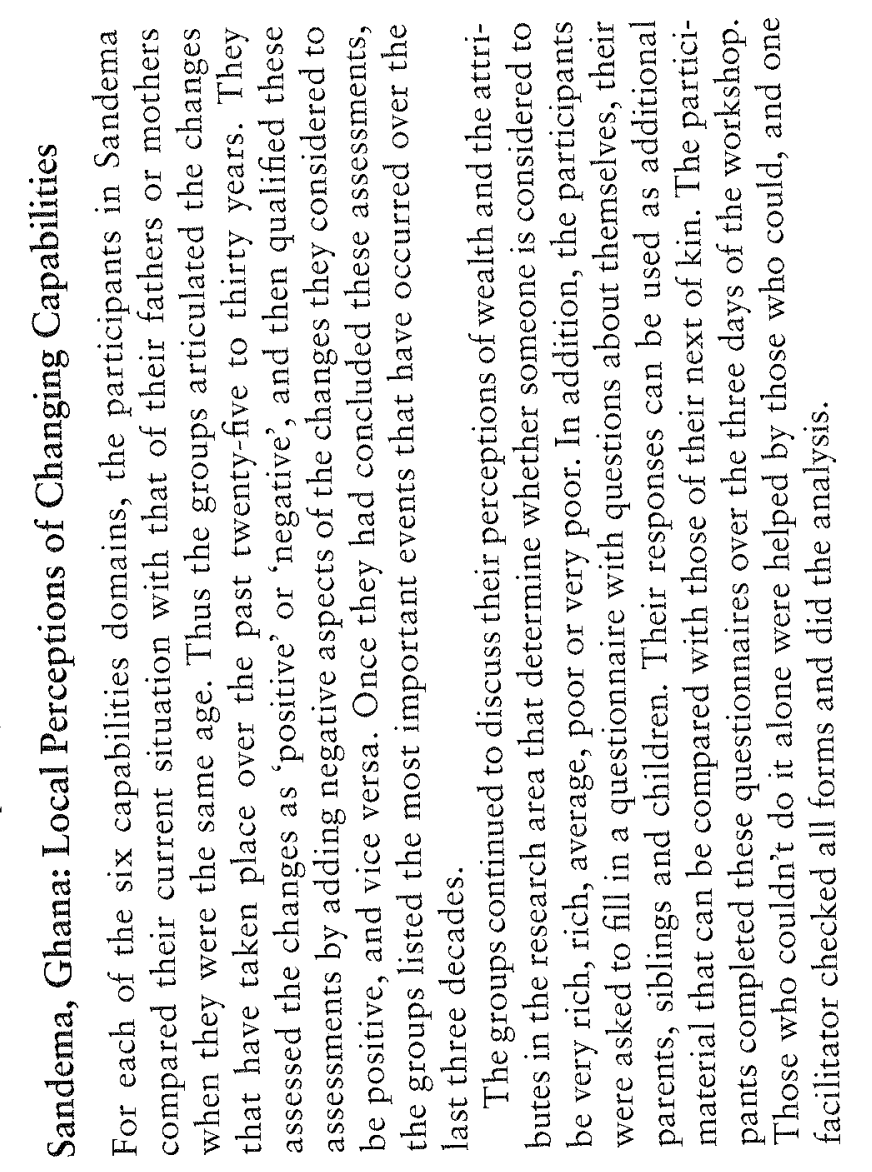

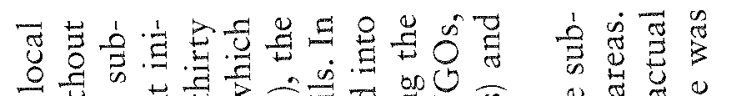

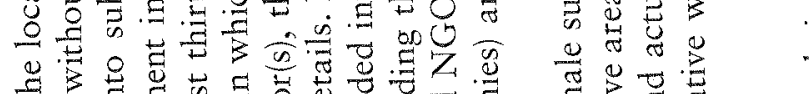

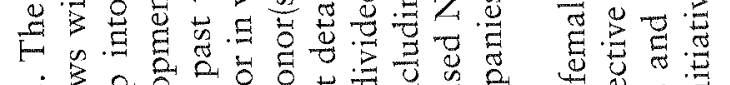

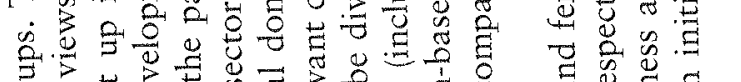

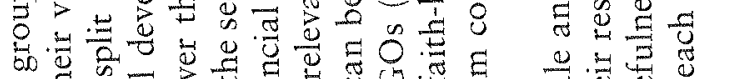

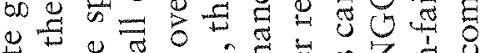

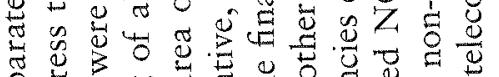

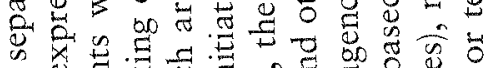

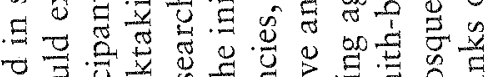

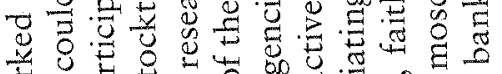

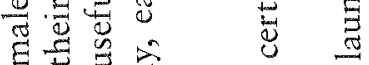
욤.

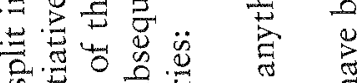

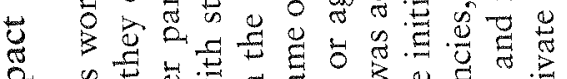
क.

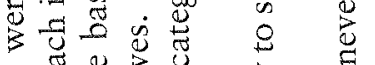

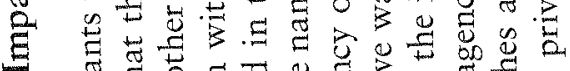

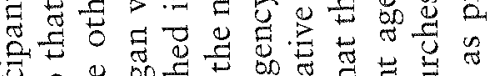

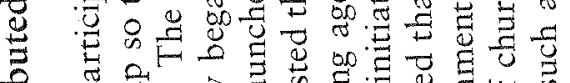

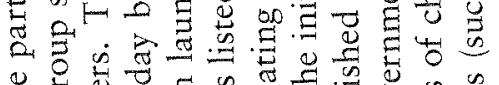

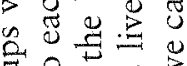

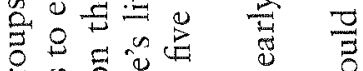

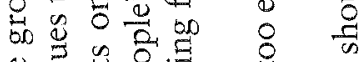

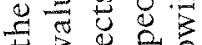
$>\frac{2}{2}$ 苛

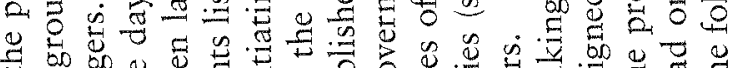

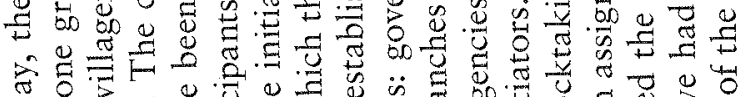

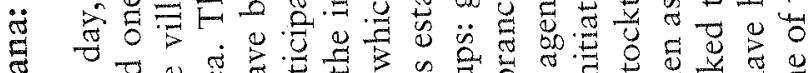

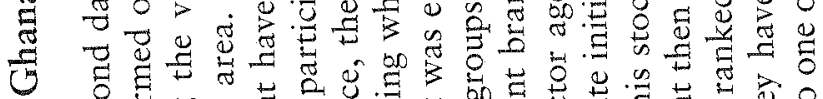

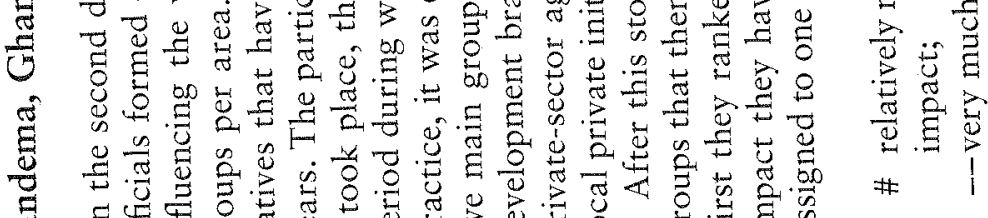
刃 $\approx$ 工

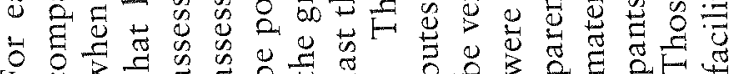

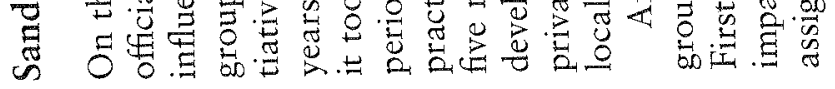

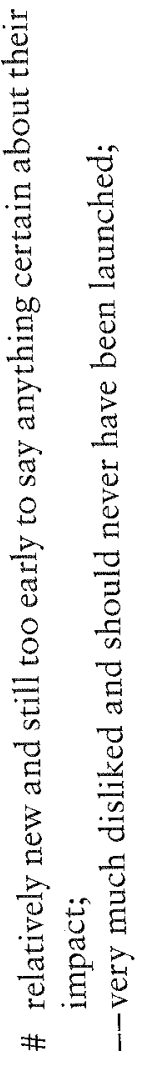

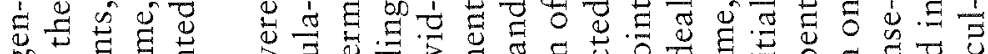

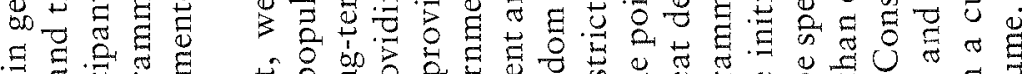

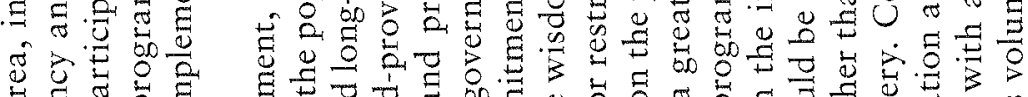

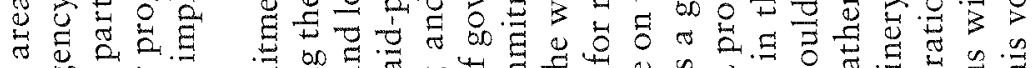

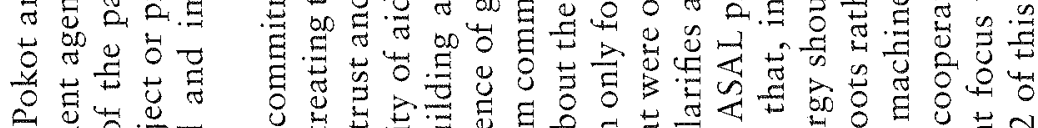

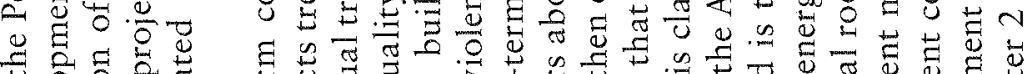

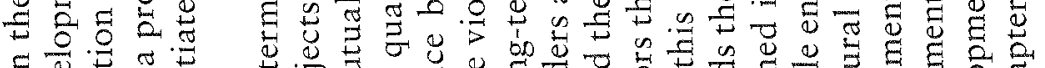

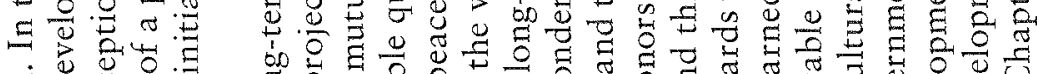

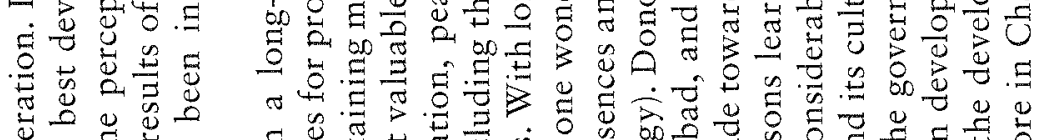

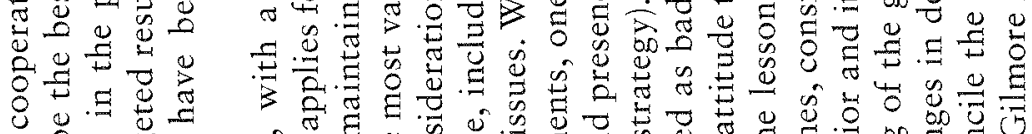

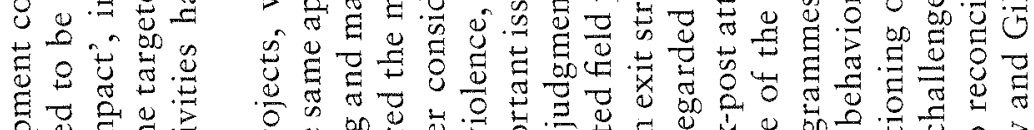

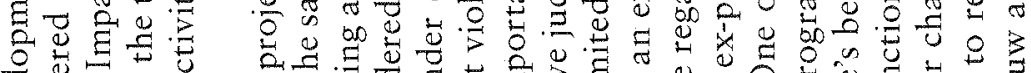

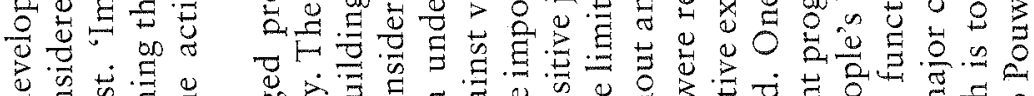

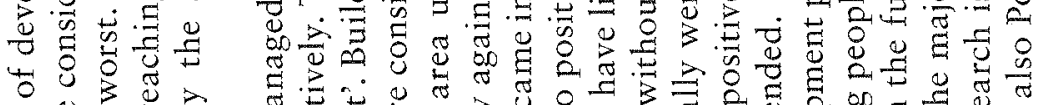

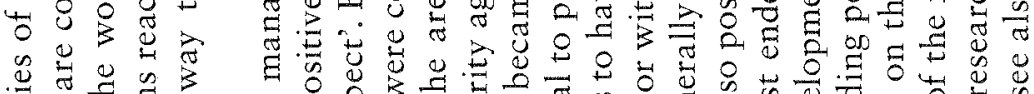

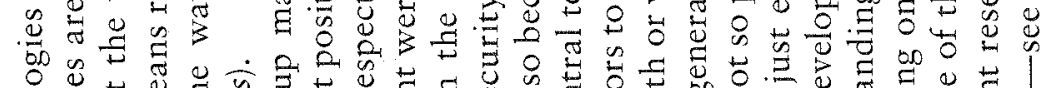

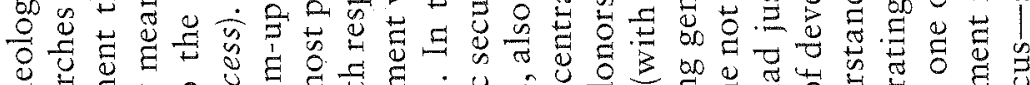

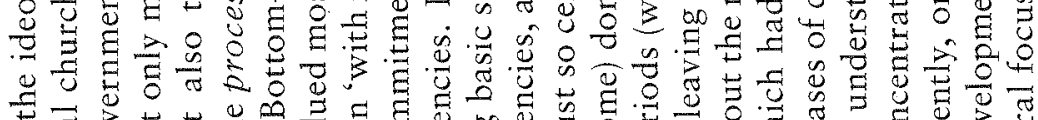

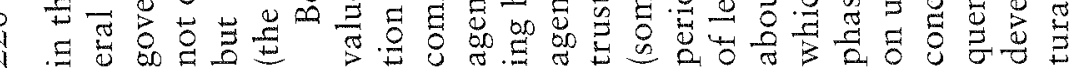

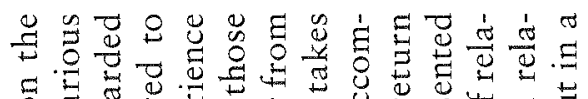

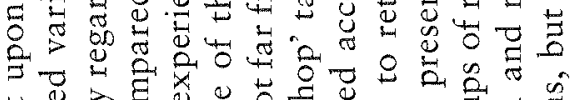

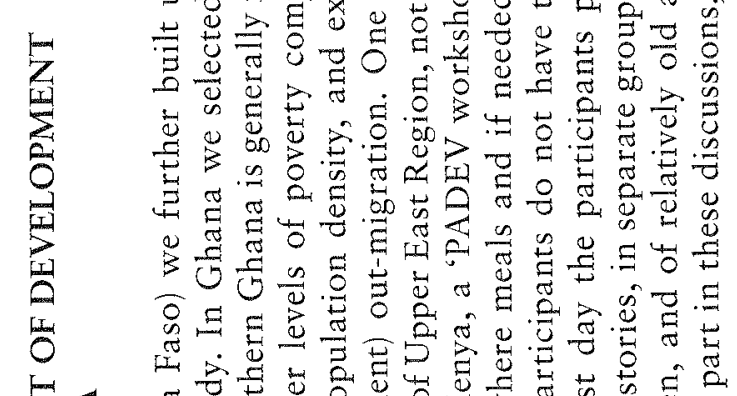

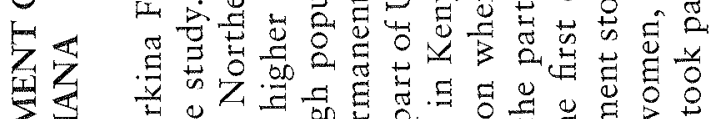

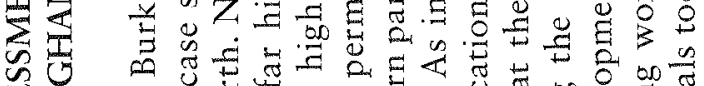

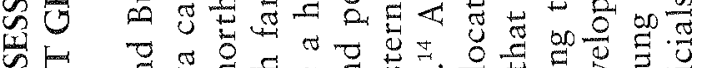

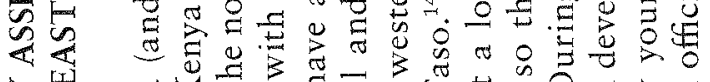

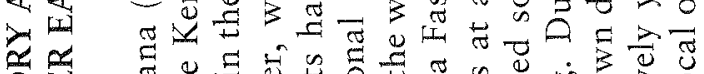

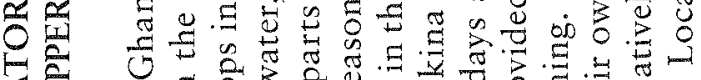

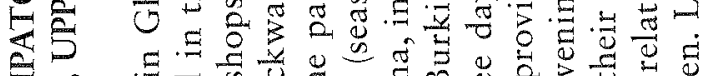

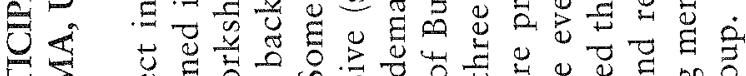

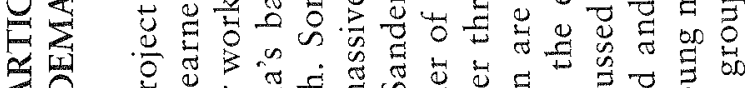

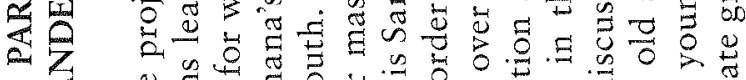
n क

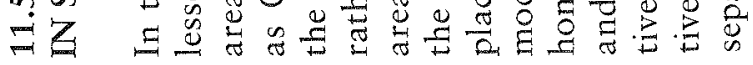




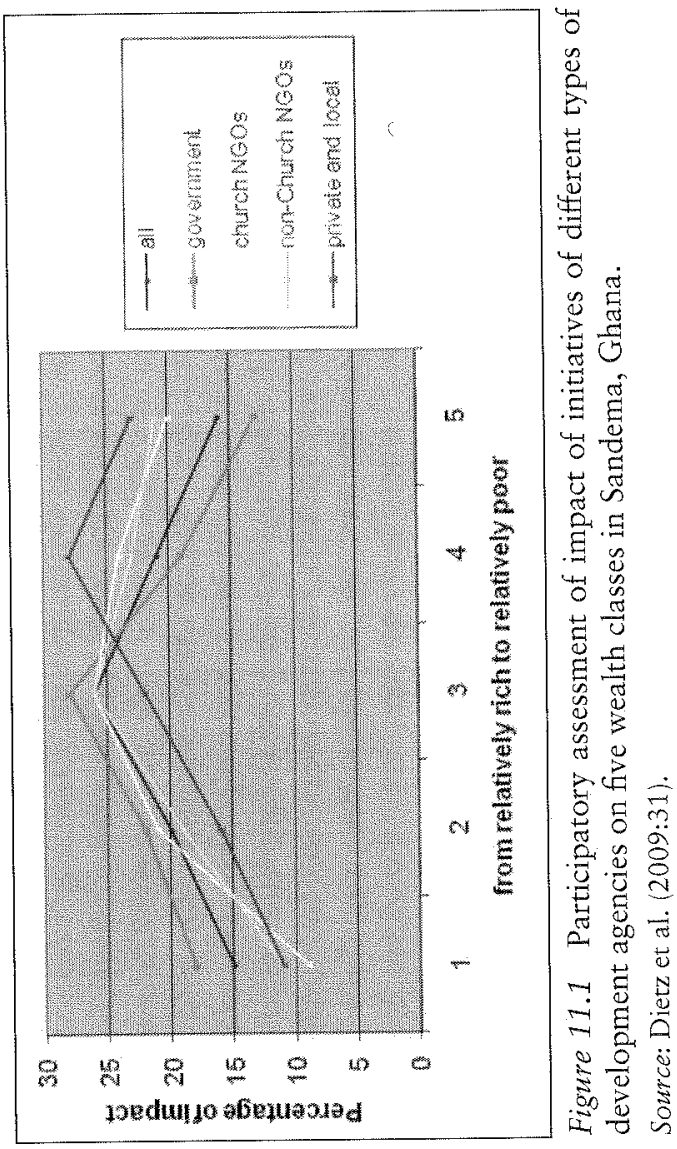

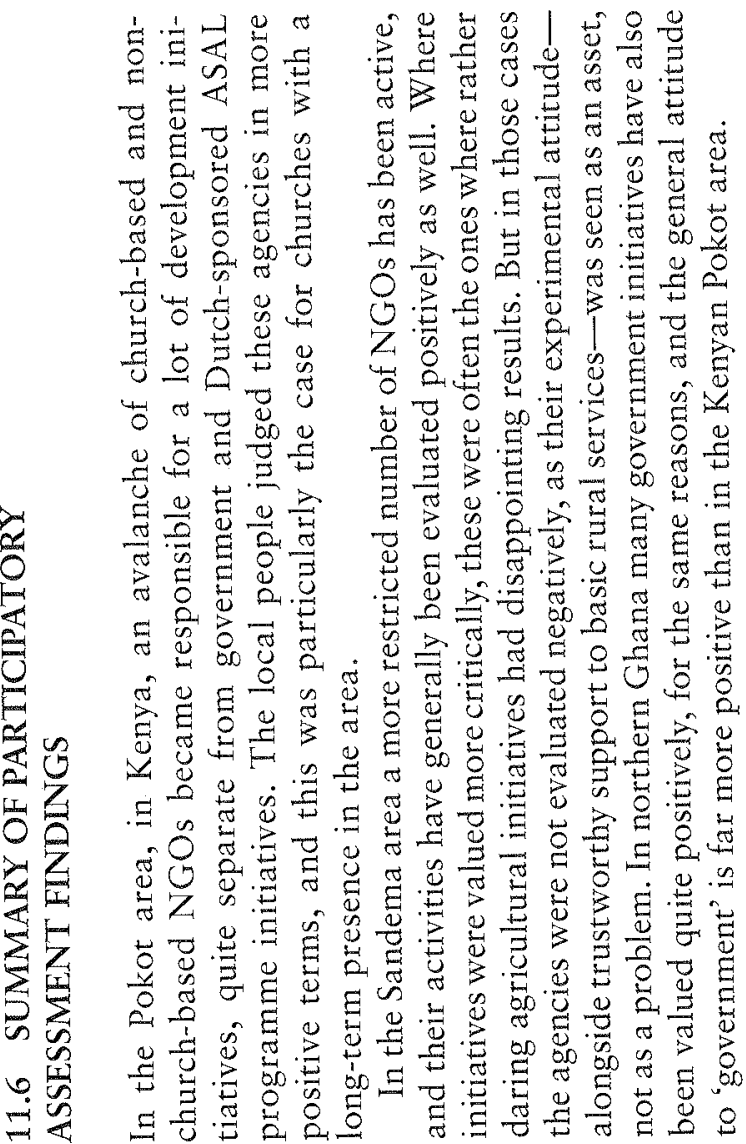

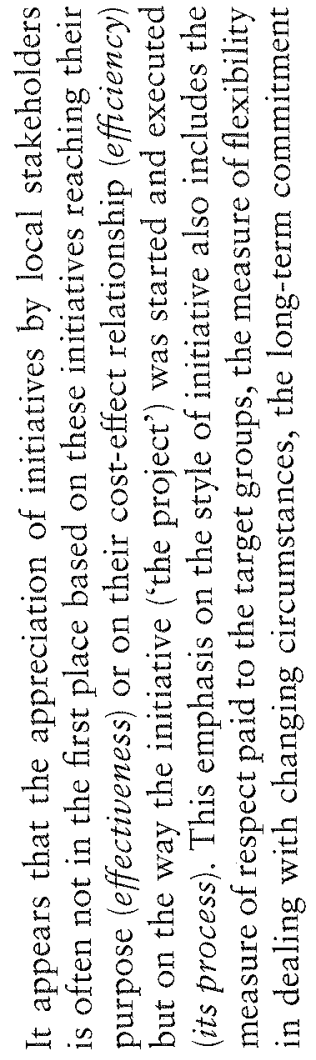
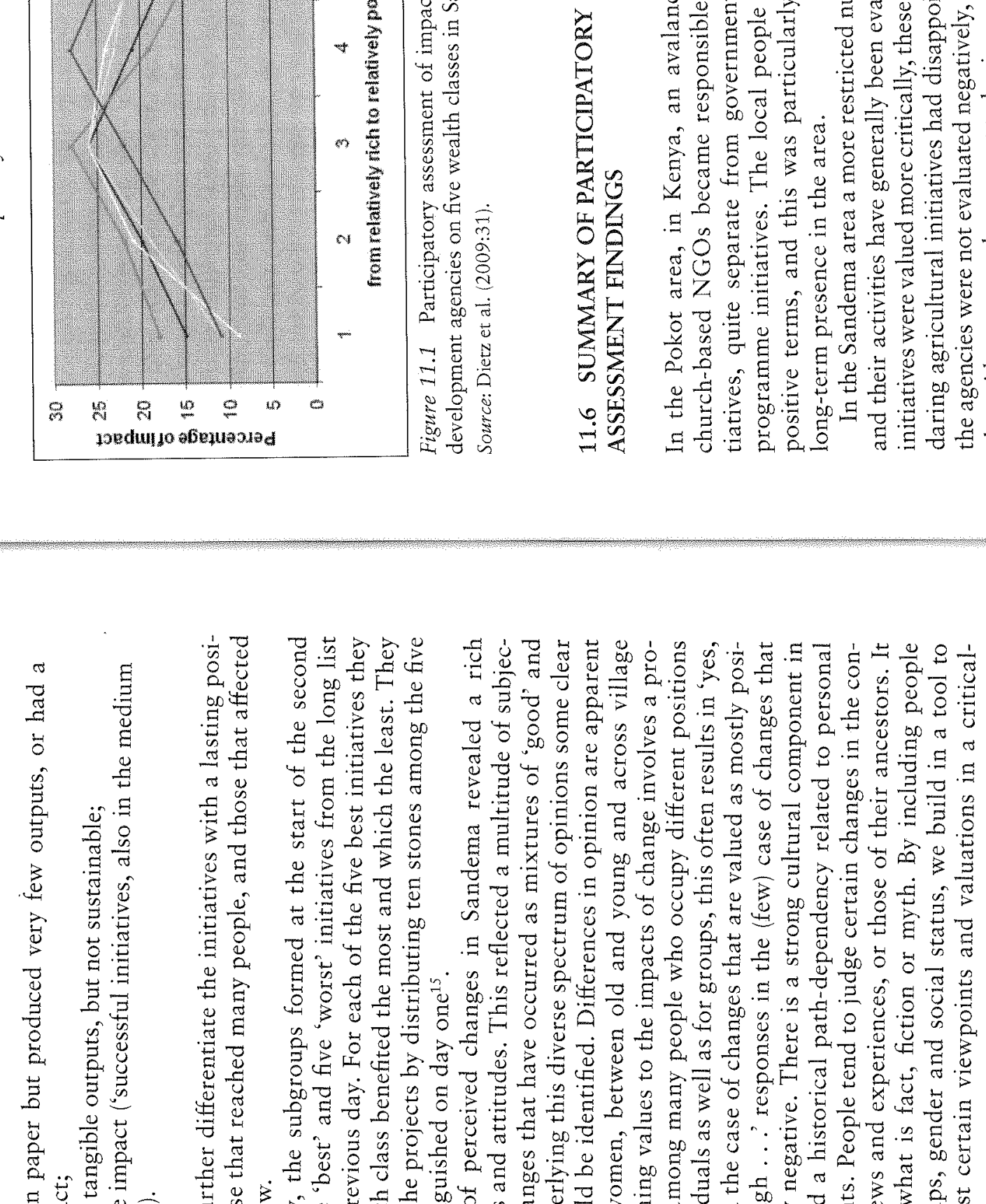

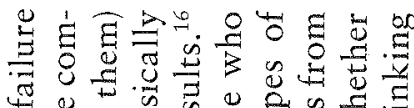

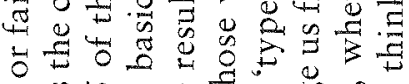

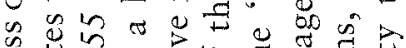

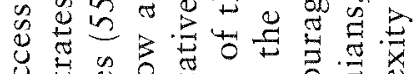

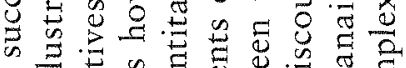

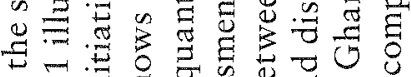

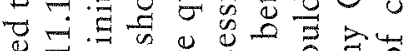

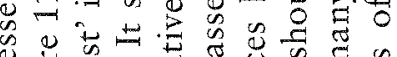

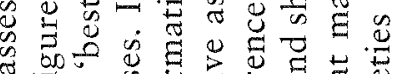
$\approx 600000$

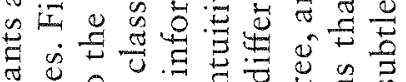

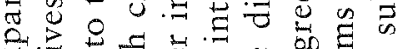

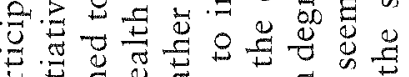

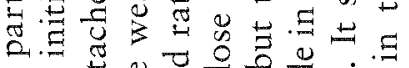

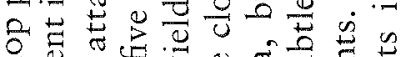

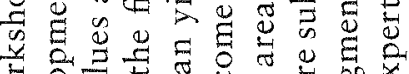

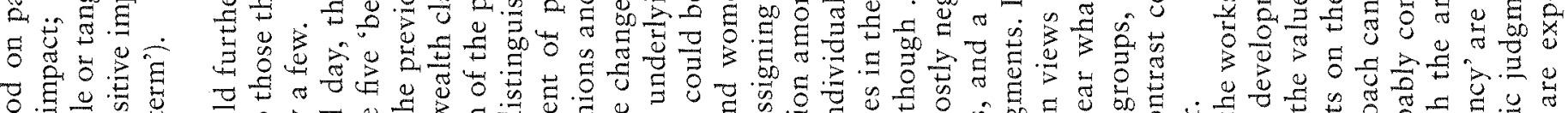

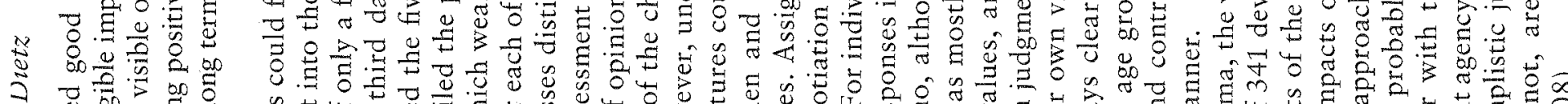

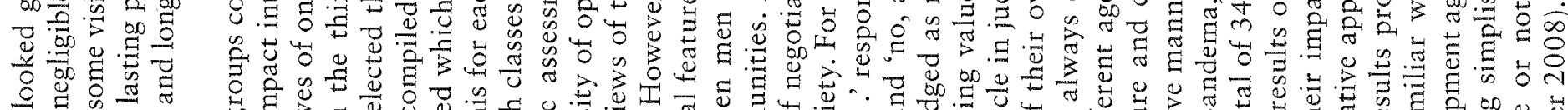
Do. F. 


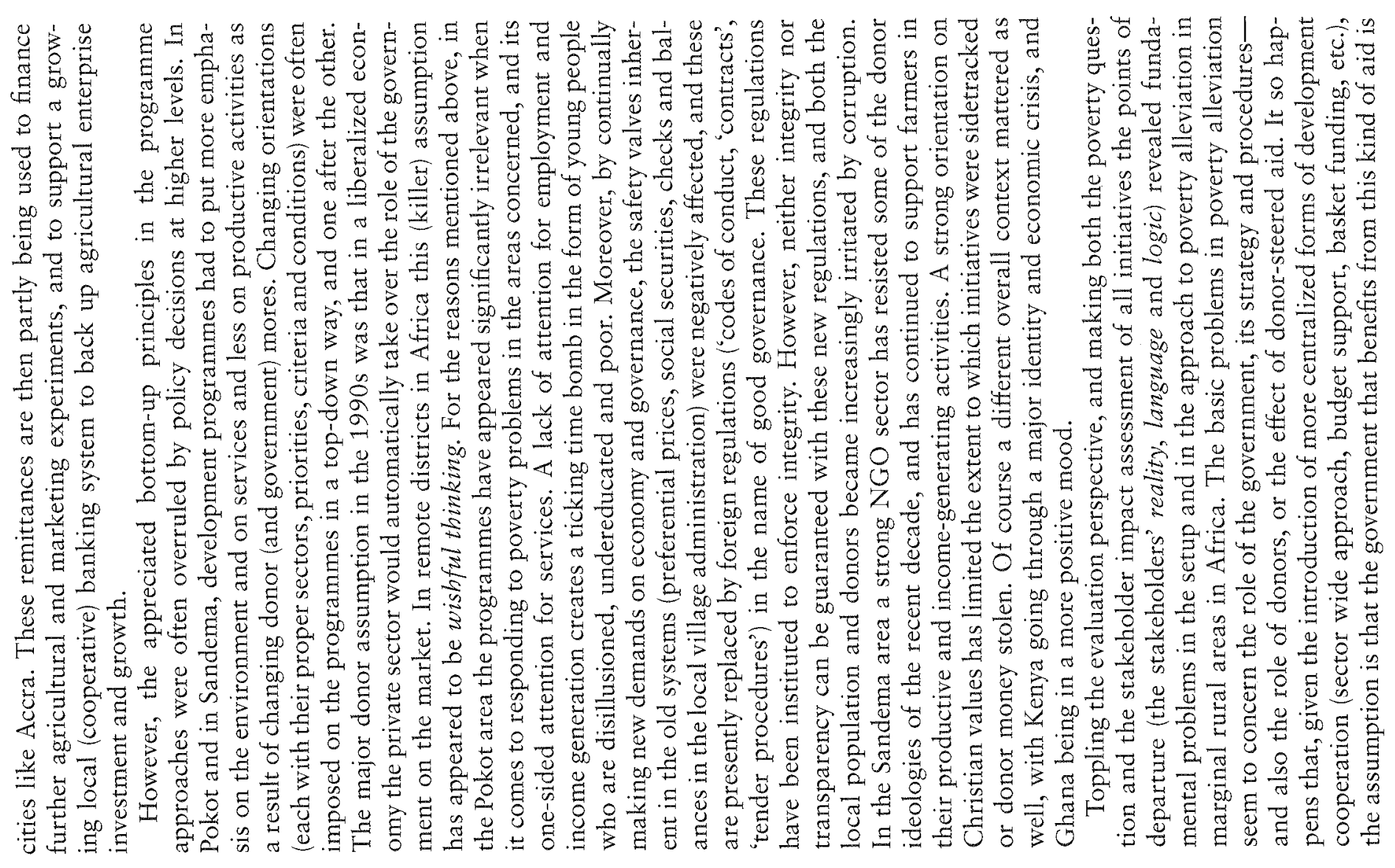

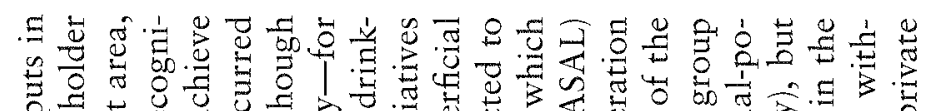

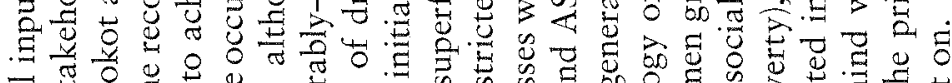

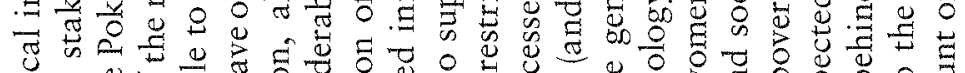

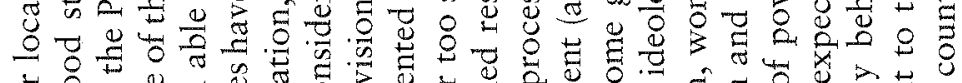

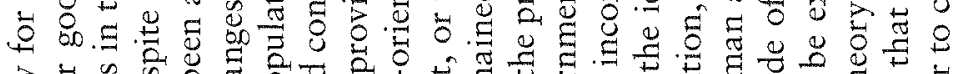

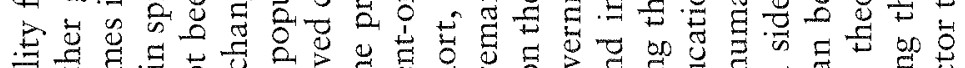

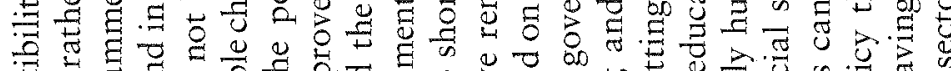

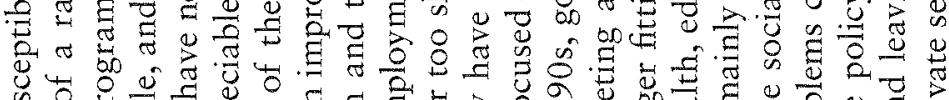

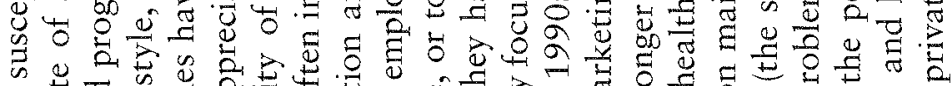
乡

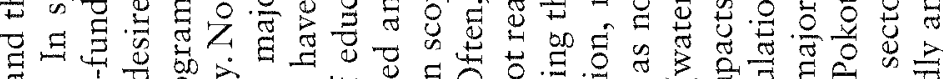

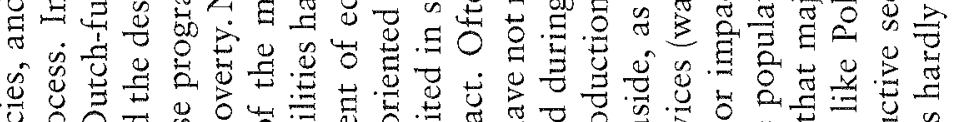

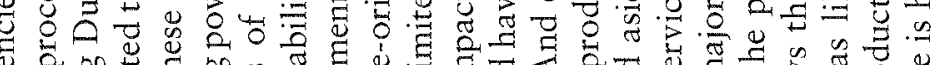

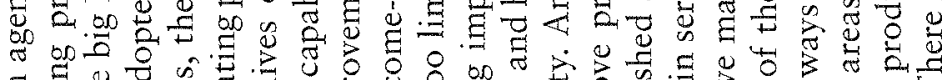

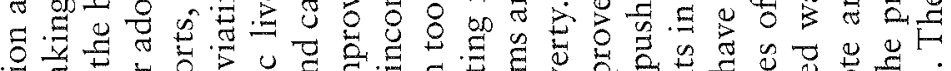

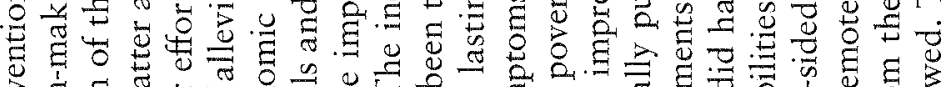

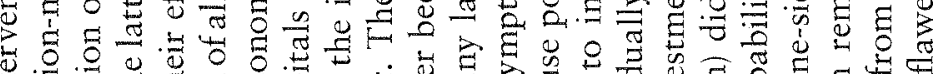

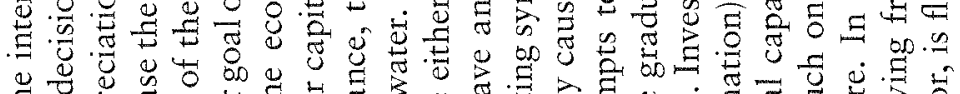

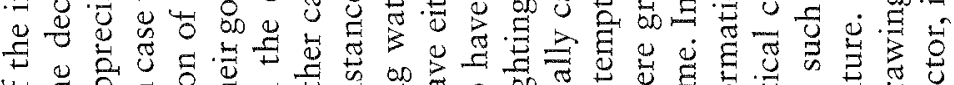

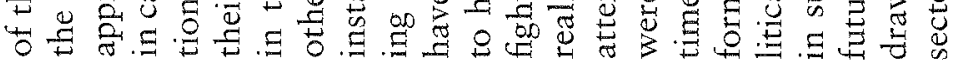

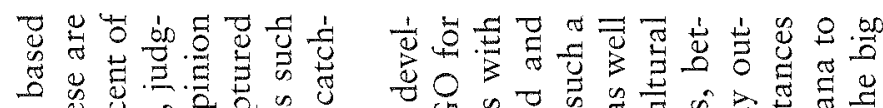

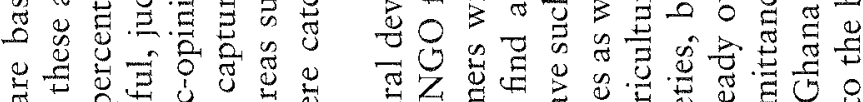

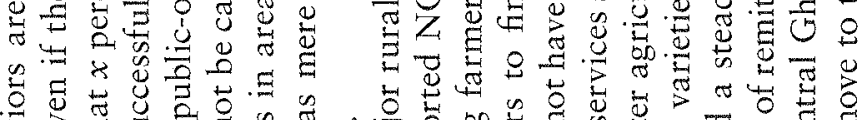

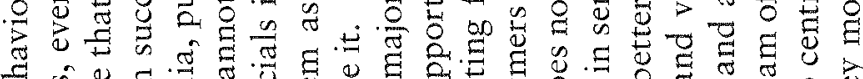

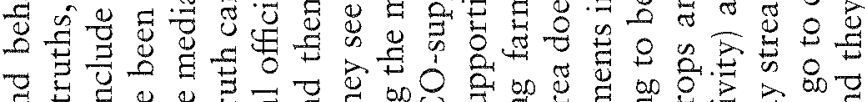

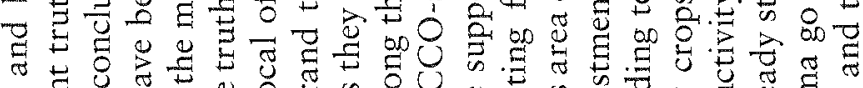

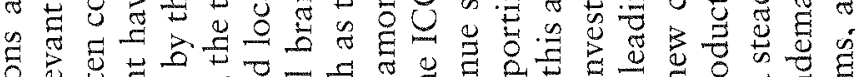

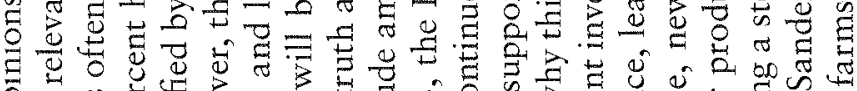

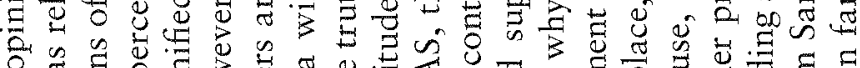
क 0 .

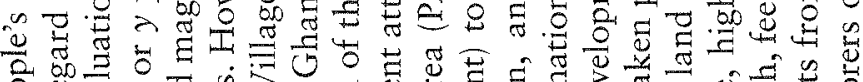

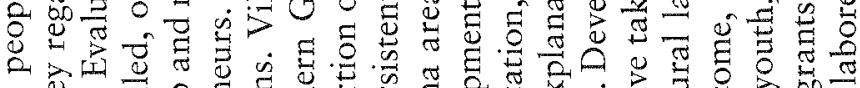

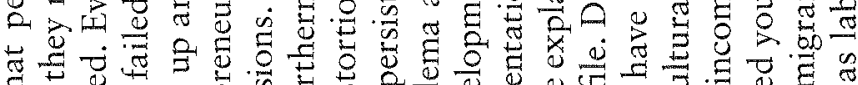

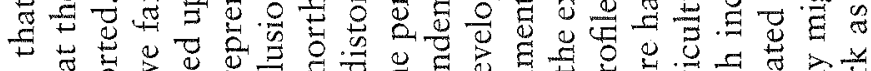

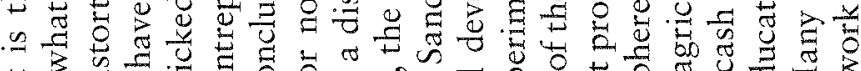

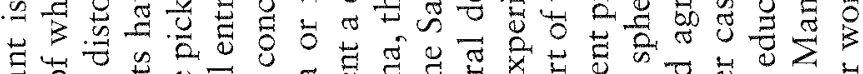

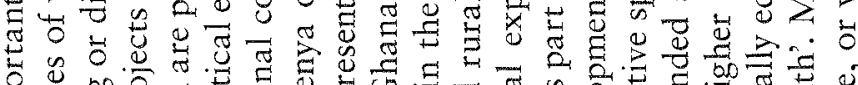

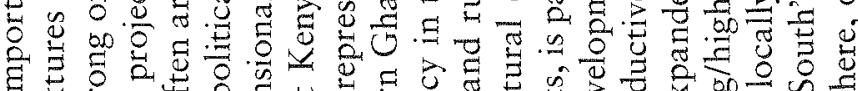

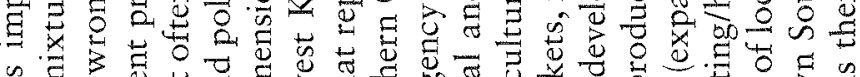

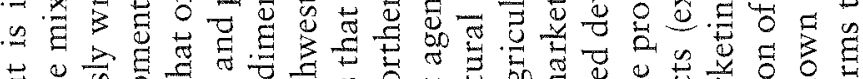

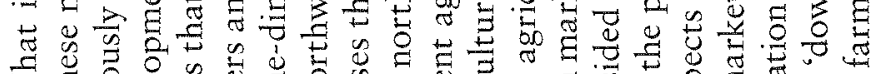

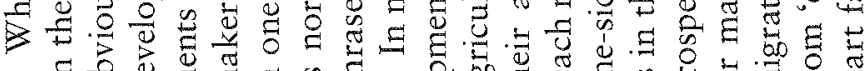

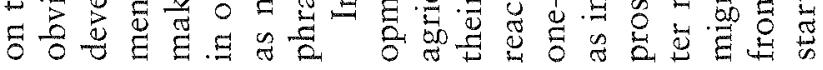




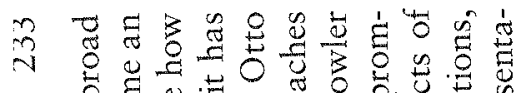

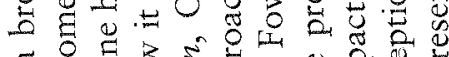

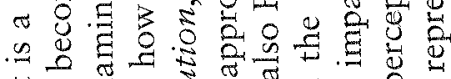

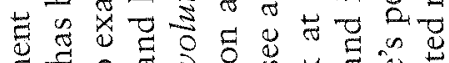

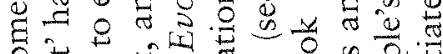

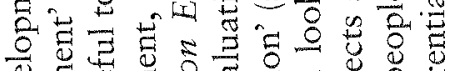

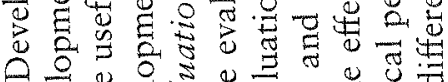

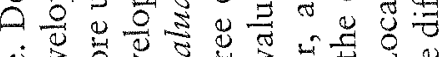

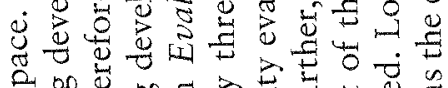
क op 巳 ब

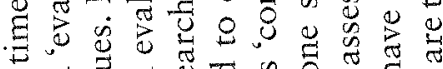

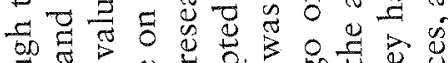

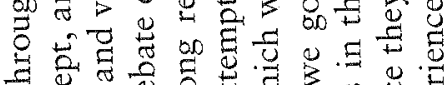

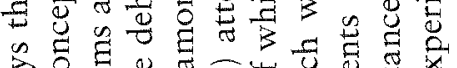

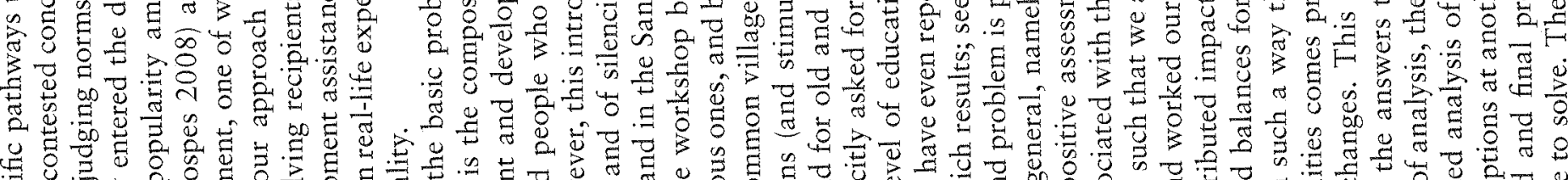

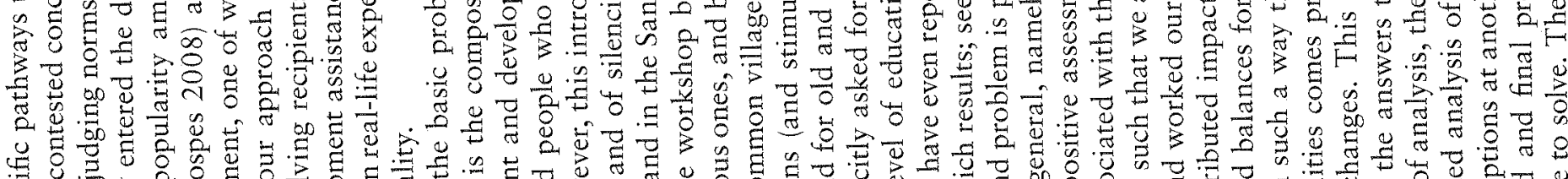

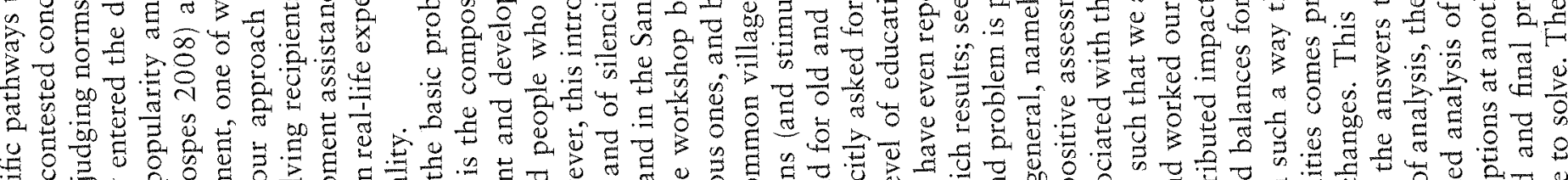

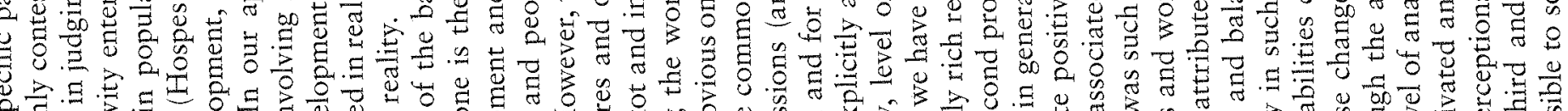

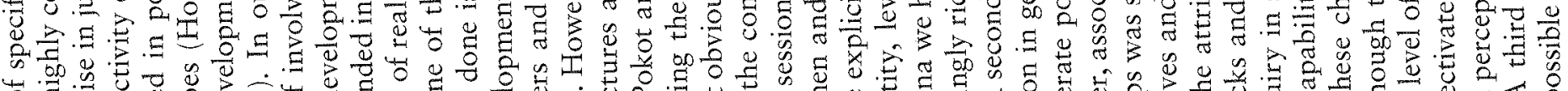

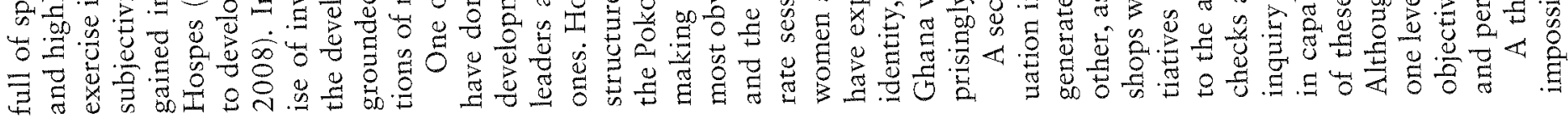

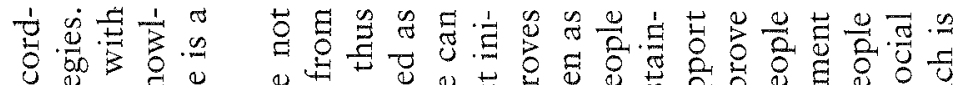
Uั

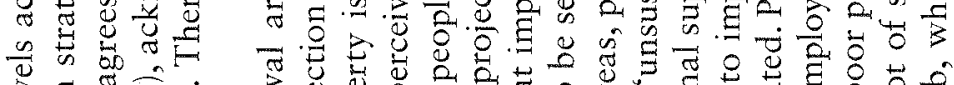

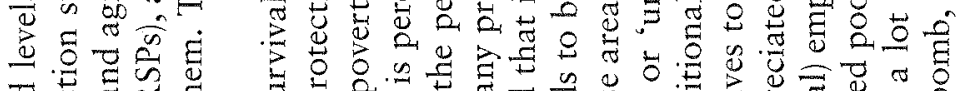

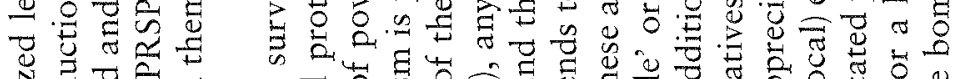

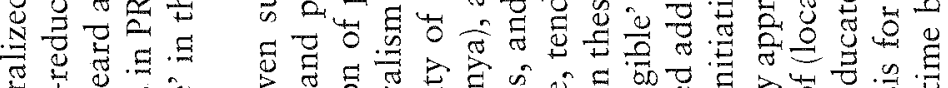

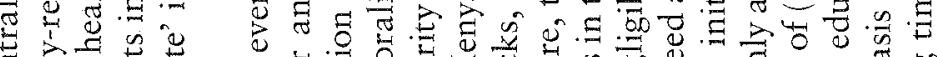

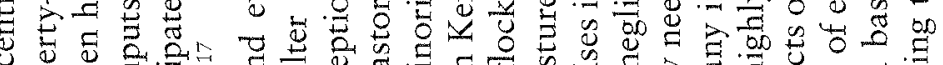

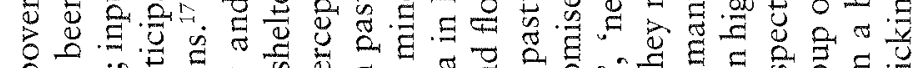

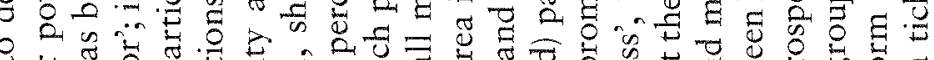

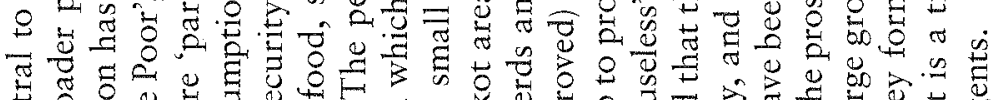

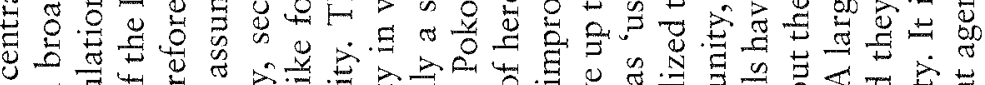

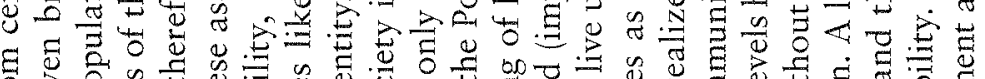

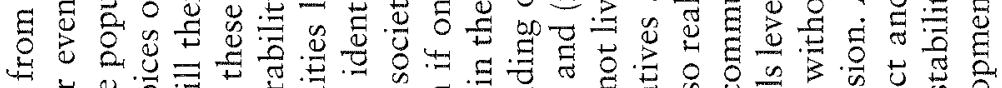
品

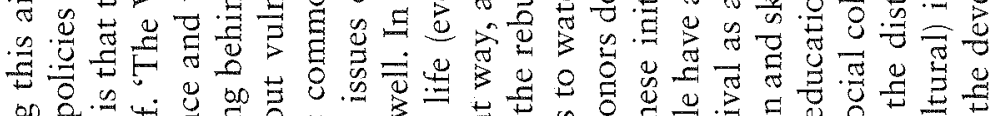
on

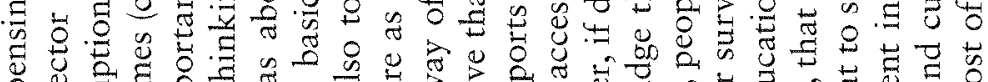

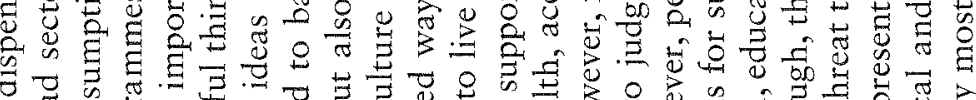

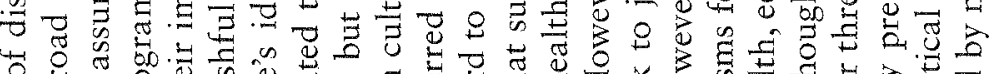

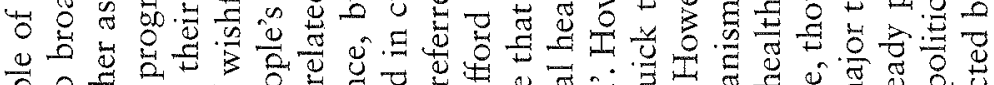

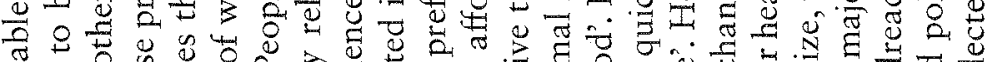
若

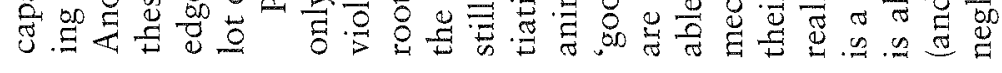

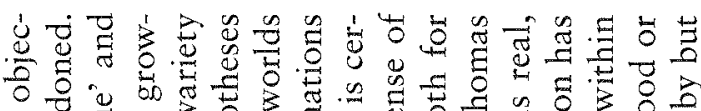

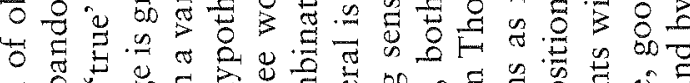

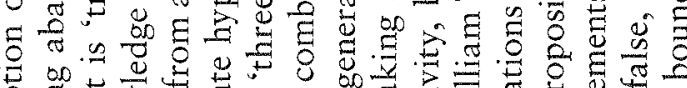

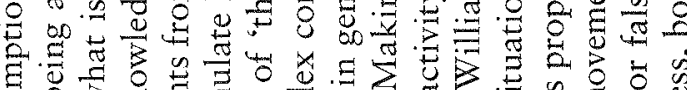

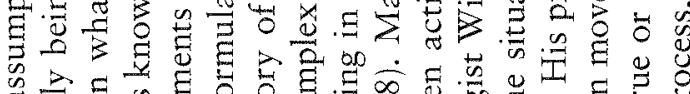

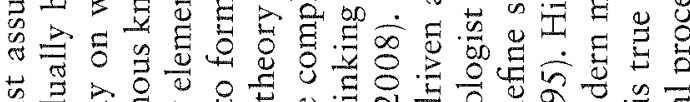

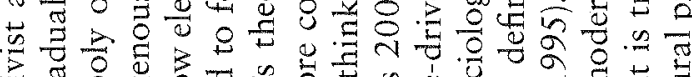

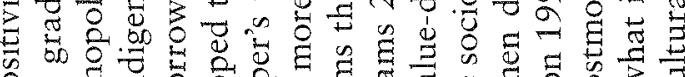

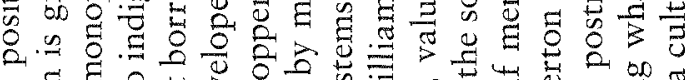

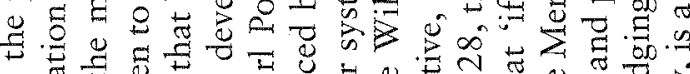
ง E.

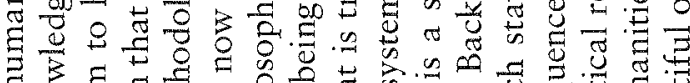

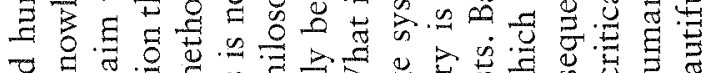

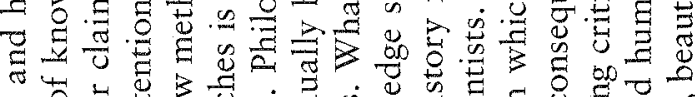

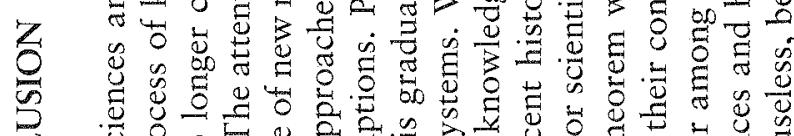

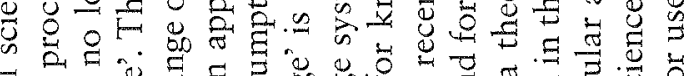

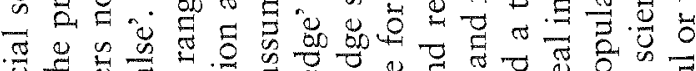

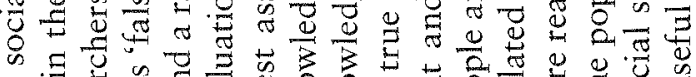
\%

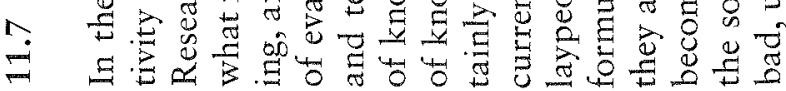




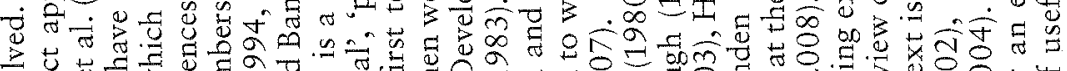

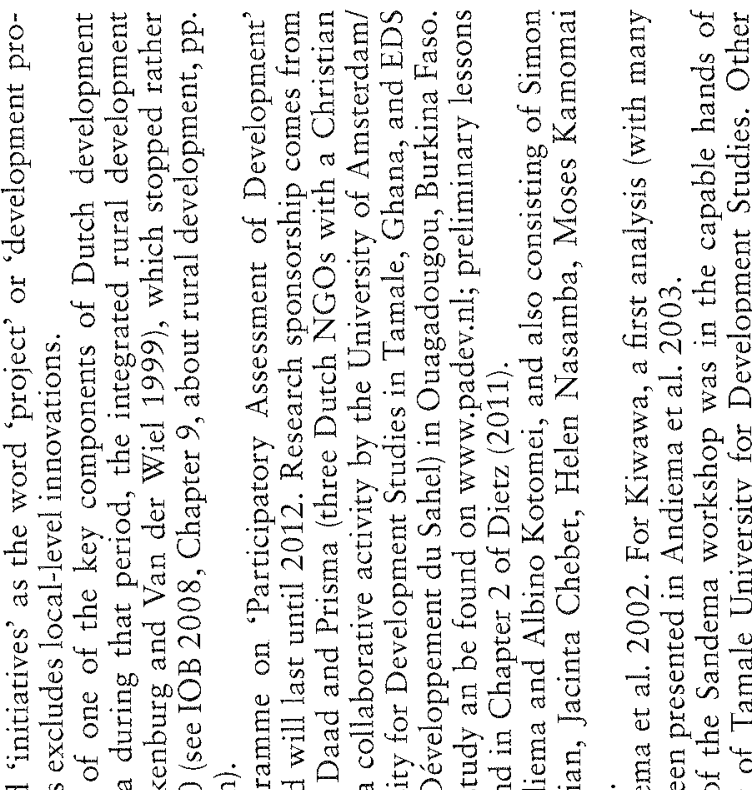

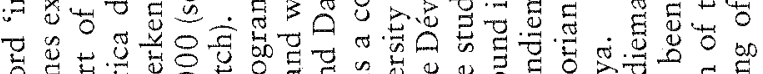

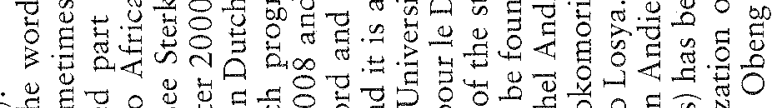

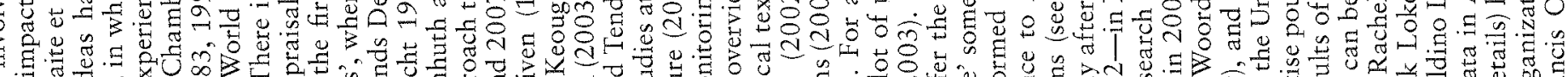
E. 产哥. I

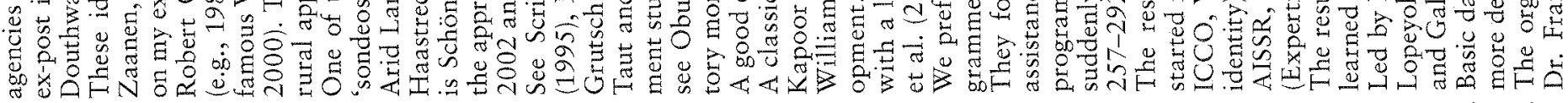

$\dot{0}$ in $\dot{0}$

$\dot{\circ} \sim \dot{\infty}$

$\sigma \stackrel{\circ}{\circ}$

$\dot{\exists}$

¿ $\rightarrow \dot{\square}$

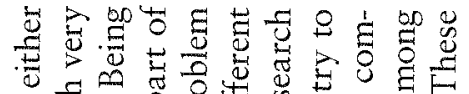

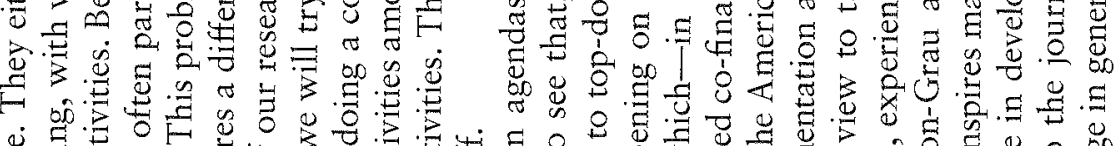

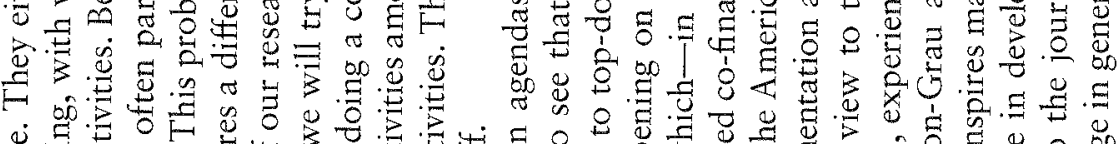

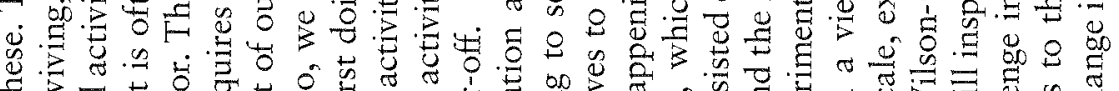

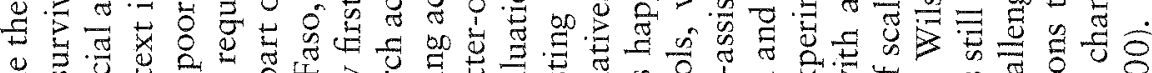
至

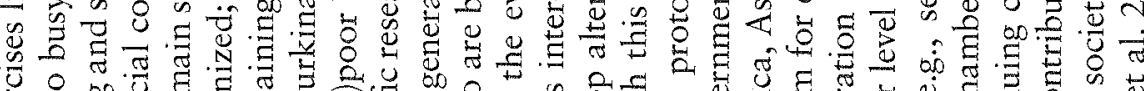

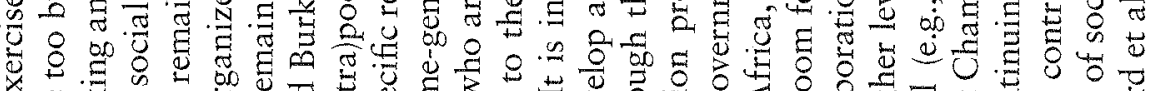

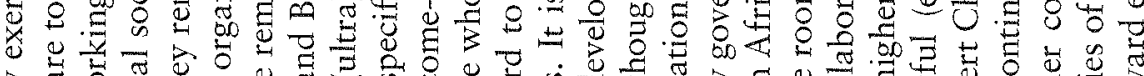

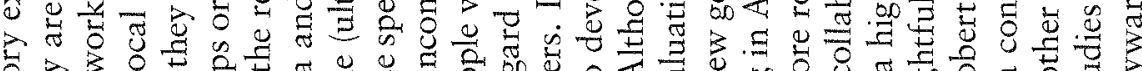

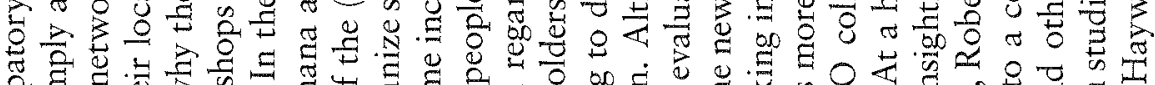

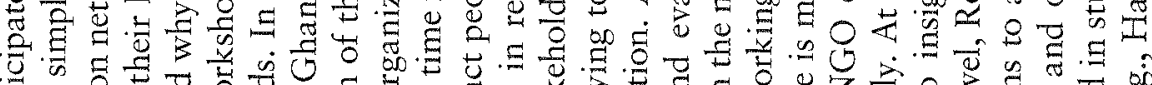

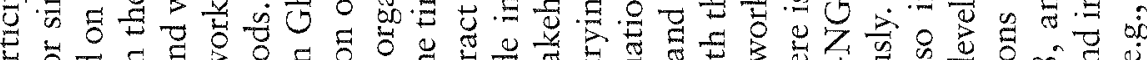

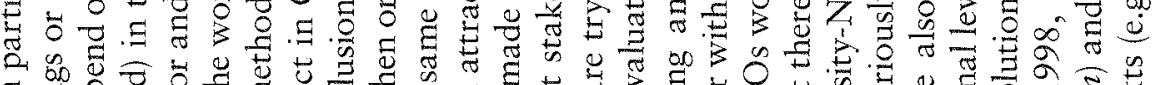

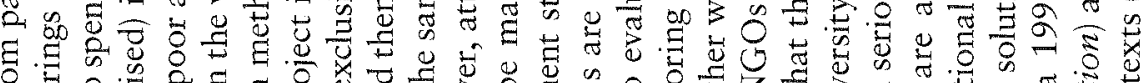

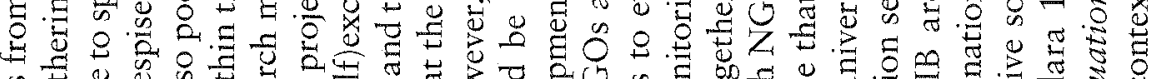

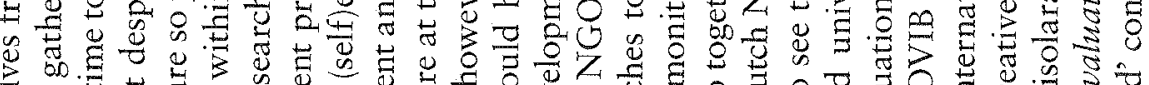

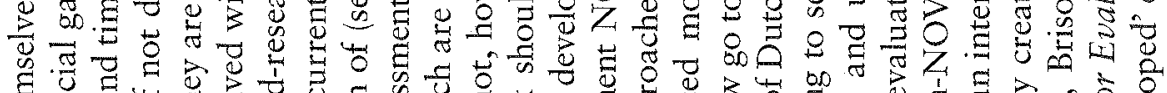

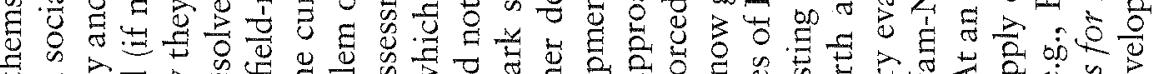

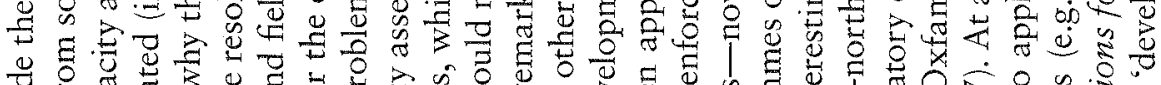

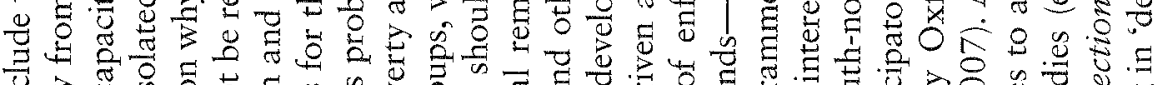

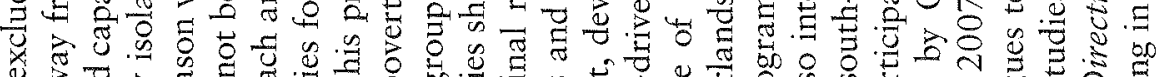

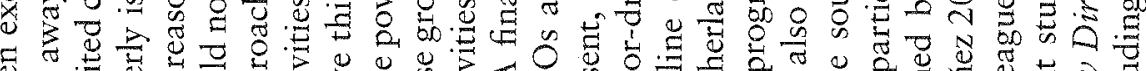

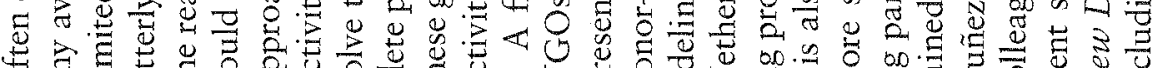

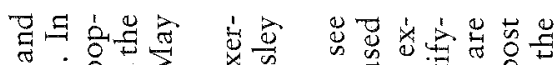

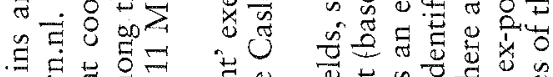

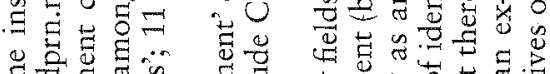

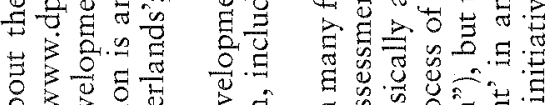

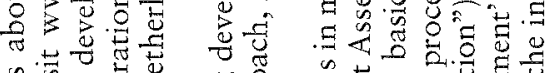

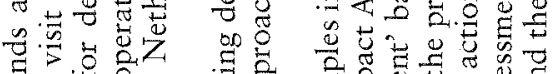

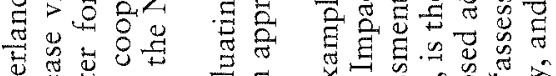

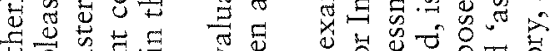

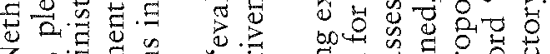

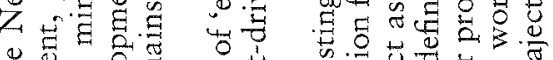

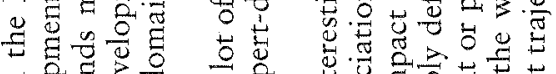

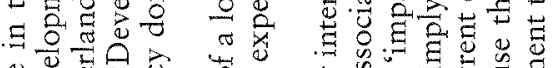

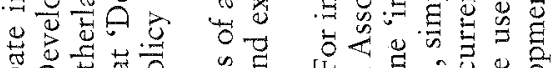

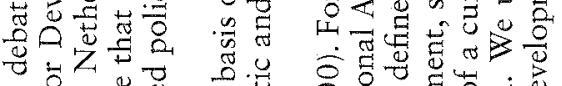
눈

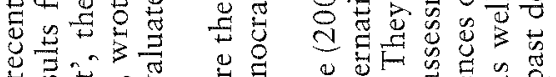

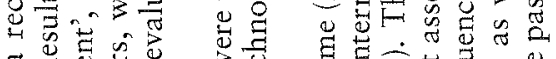

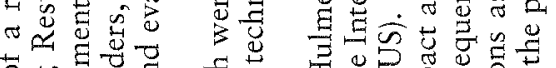

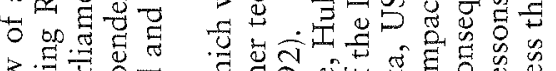

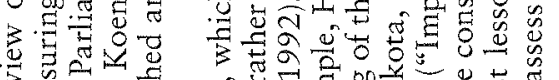

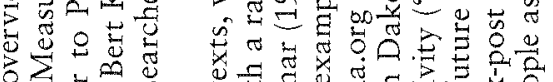

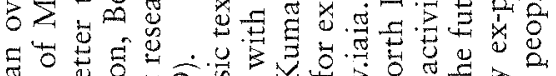

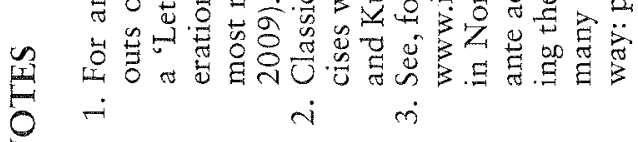




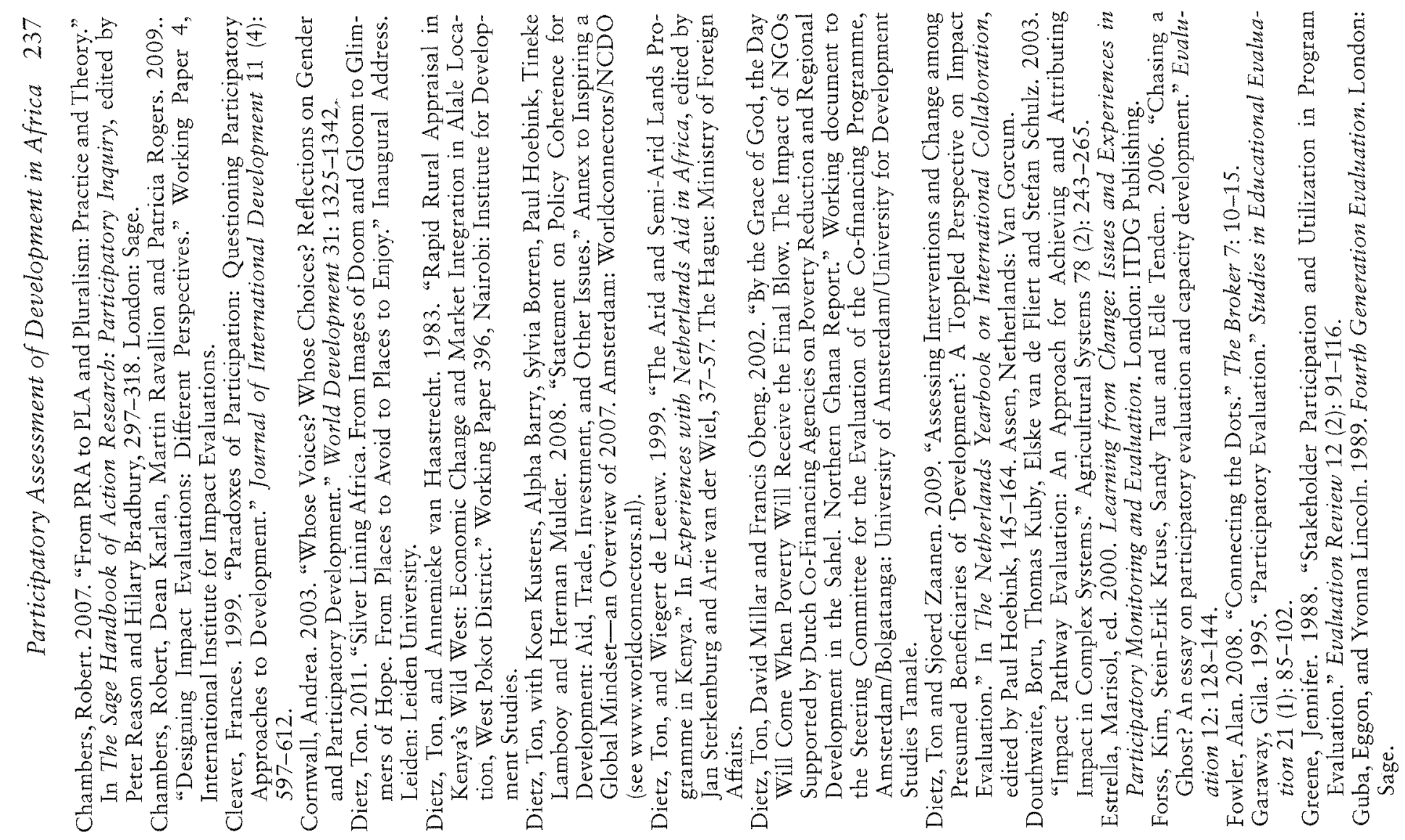

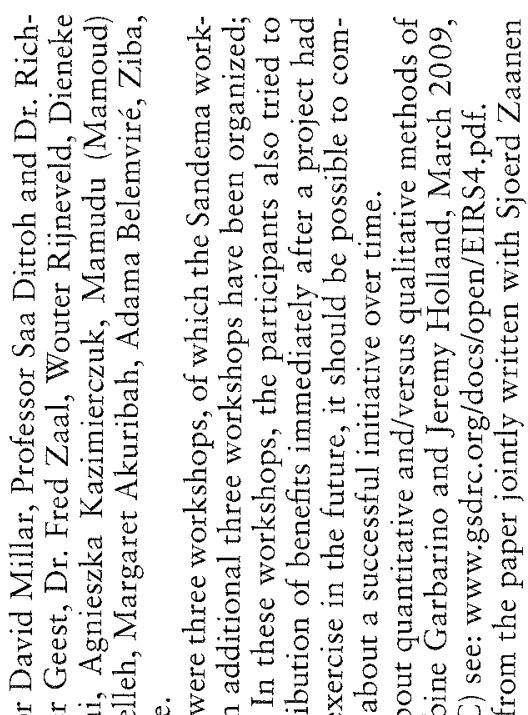

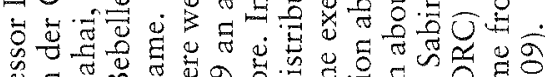

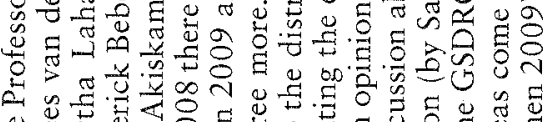

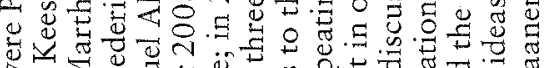

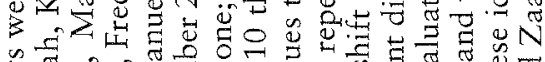

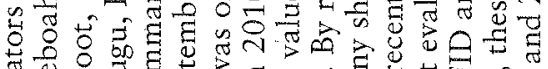

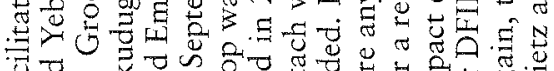

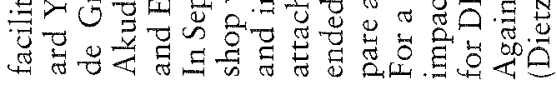

$$
\text { in } \stackrel{0}{\rightarrow}
$$

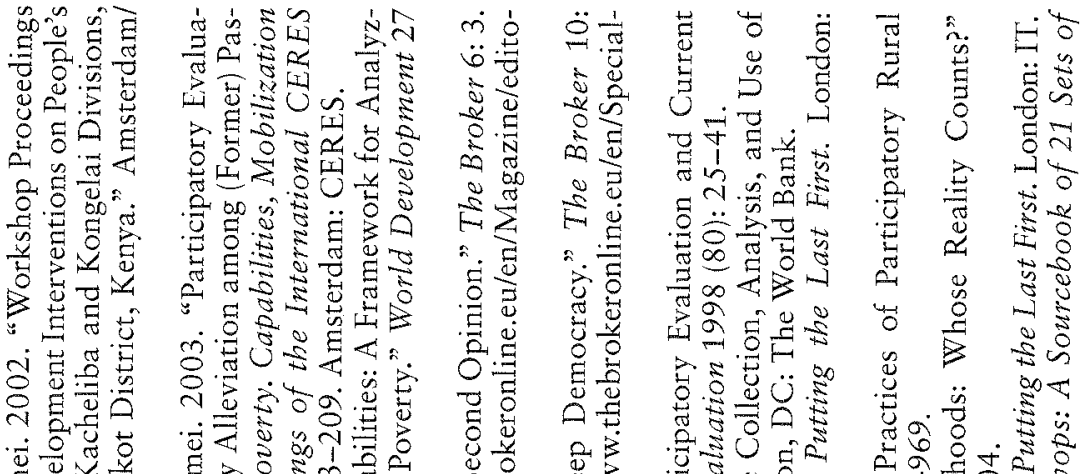

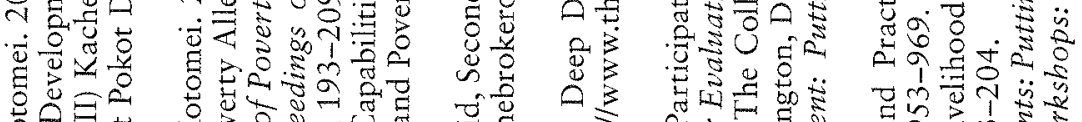

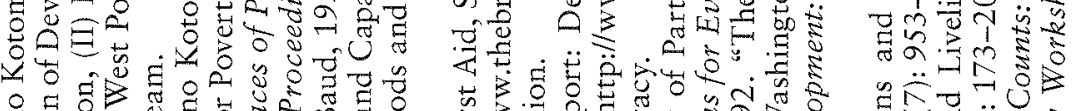

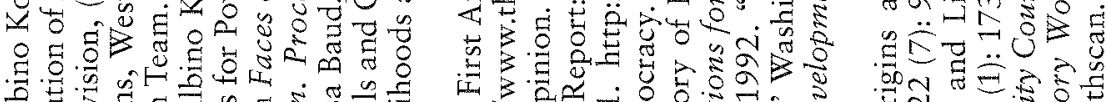

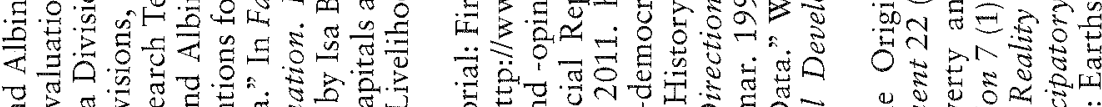

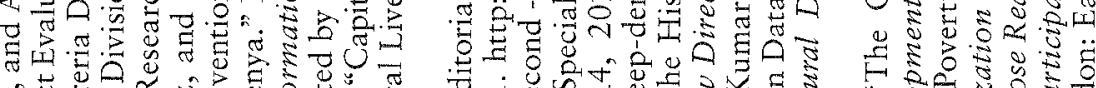

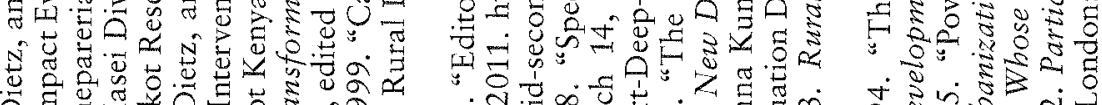

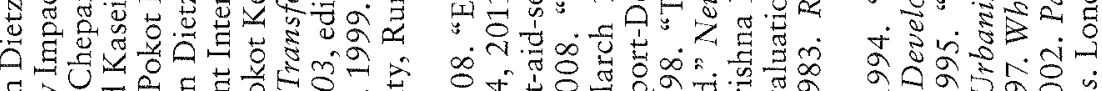

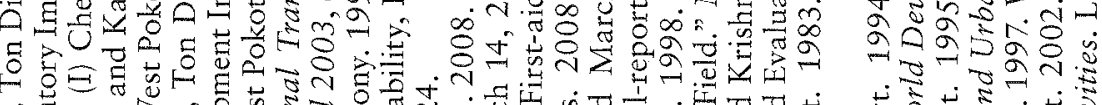

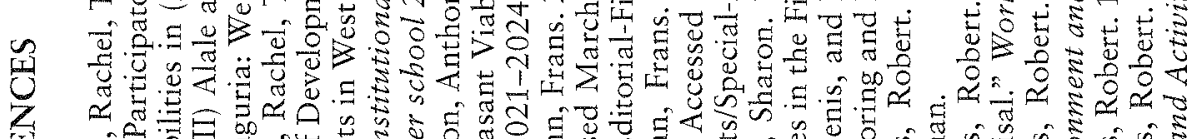

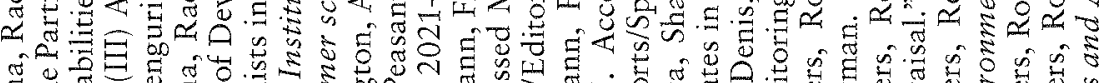

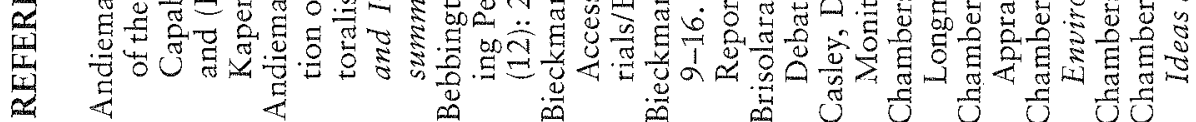



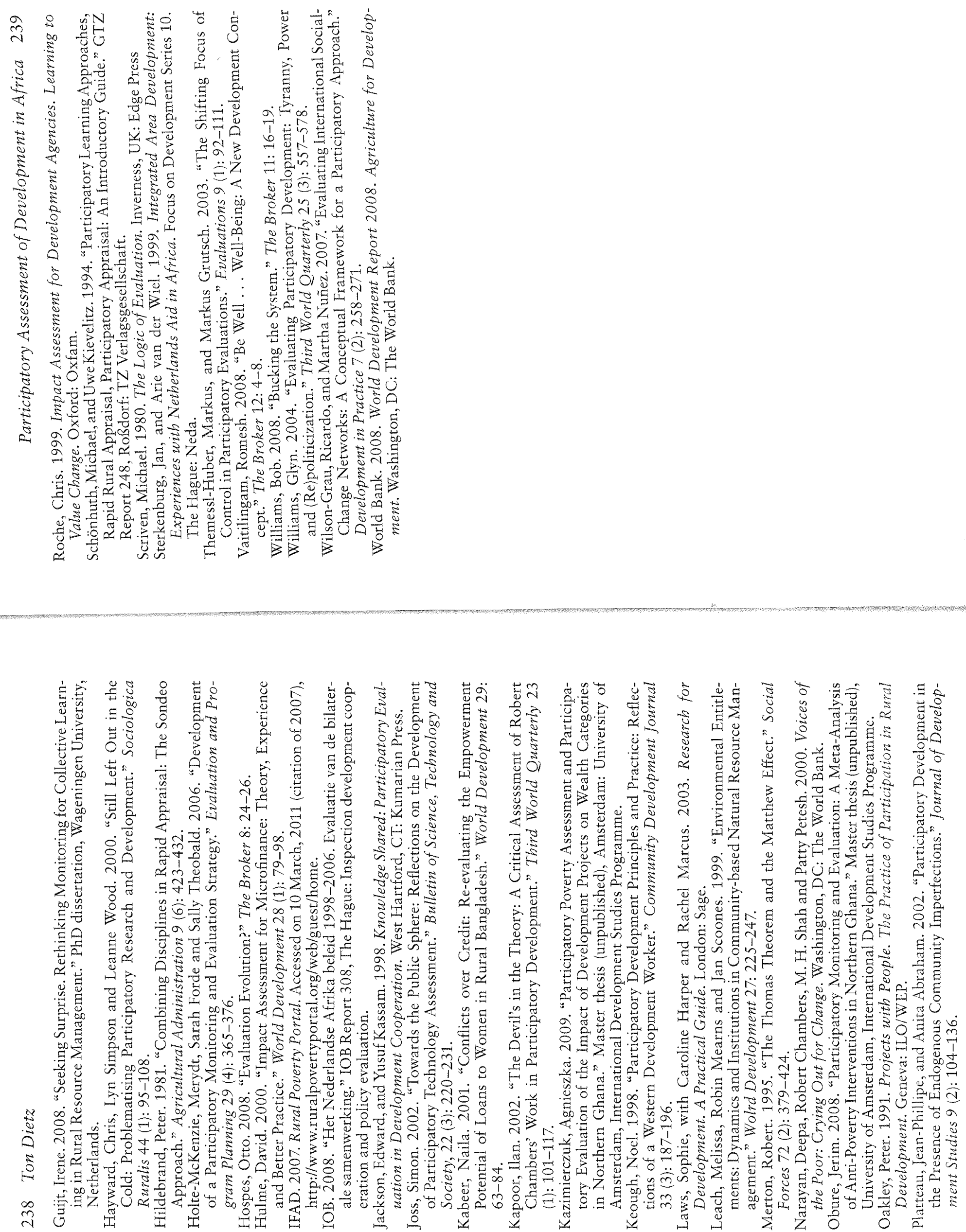